\title{
UNHEALTHY PRESSURE: HOW PHYSICIAN PAY DEMANDS PUT THE SQUEEZE ON PROVINCIAL HEALTH-CARE BUDGETS
}

Hugh M. Grant ${ }^{\dagger}$

Department of Economics, University of Winnipeg, Winnipeg, Manitoba

Jeremiah Hurley ${ }^{\dagger}$

Department of Economics and Centre for Health Economics and Policy

McMaster University, Hamilton, Ontario

\section{SUMMARY}

In the 11 years since the Romanow Commission warned that the income of physicians was threatening to become a significant driver of Canadian health-care costs, doctors in this country proceeded to chalk up some of their most rapid gains in earnings since the implementation of medicare.

Since 2000, the gap between what the average physician makes, and what the average fully employed Canadian worker earns, has diverged like never before. In the last decade, the average doctor went from earning three-and-a-half times the average Canadian worker's salary, to earning nearly four-and-a-half times as much, a more than 25 per cent relative increase. In constant dollars, today's average Canadian physician is earning about 30 per cent more than he or she was just a decade ago. All of this has occurred while physicians have actually provided slightly fewer services to patients.

Since the implementation of medicare, the payment of doctors has been rather a matter of politics, as provinces became the ultimate paymasters for health-care personnel. The natural result was an ongoing competition between provinces and physicians for public support, each with its own claim to being the guardian of public health care. In the last two decades, however, doctors have succeeded in outmaneuvering governments, marshaling greater public support for higher pay for their work, even as provinces have been more often viewed as underfunding basic health care needs.

There are signs that this may have finally gone too far: Ontario was recently able to freeze remuneration for doctors in a negotiated contract deal and Alberta shortly after imposed a unilateral settlement on its doctors after breaking off negotiations. Stories about "millionaire doctors" are now proliferating in the mainstream media and, as provinces across the countries struggle with deficits, the public's sympathy appears to be shifting. There were periods, during the ' 70 s and ' 90 s, when governments were successful in holding back the growth in doctors' fees, to the point where physicians saw their purchasing power shrink. If Canadians are now questioning where the priorities of doctors truly lie - whether its preserving health care or enriching themselves - the provinces can only gain more leverage in future negotiations with doctors.

Physicians in the Canadian health-care system are entrusted with a special and protected role, and it behooves medical associations to bear in mind their additional responsibility to promote public health-care objectives. The current collective bargaining model has resulted in provinces pressured into buying healthcare peace by agreeing to continually ratchet up doctors' pay. It is difficult to see how that can continue. It is time that doctors began working with policy-makers on a new model, one that puts less emphasis on profiting doctors, and more emphasis on promoting a sustainable health-care system for everyone.

\footnotetext{
$\dagger$ The authors wish to acknowledge the helpful comments of the anonymous referees.
} 


\section{INTRODUCTION}

Recent measures undertaken in Ontario and Alberta to curtail the rate of increase in physician incomes have refocused public debate on the cost of physicians in the delivery of health care. A central feature of Canada's health-care system is the tension between two competing sources of "legitimacy" or control: political and professional. Both the state (political) and physicians (professional) claim the ability to best define the health-care needs of the population and the manner in which these needs are best met. The uneasy compromise reached under Canada's single-payer, public health insurance assigns to physicians a major role in the specific allocation of resources, with the state setting the overall resources available. An incomplete division of responsibilities, however, leaves areas of conflict over professional autonomy in the delivery of service and over the level of expenditures and remuneration. ${ }^{l}$

In light of the contested terrain, physician-government conflict has been managed surprisingly well. Notwithstanding the occasional industrial action - including the withdrawal of partial or complete services - and the exceptional measures undertaken by provincial health authorities to curtail expenditures on physician services in the early 1990s, disputes have been largely confined to the political arena. Since both parties derive their legitimacy from their claim to represent the public interest, both appeal for public support - physicians on the grounds that the system is underfunded and governments arguing that constraints are necessary to avoid a cost explosion. The recurring debate over whether there are too many or too few doctors is one reflection of the effort to muster public approval by professional and political authorities.

An important factor contributing historically to peaceful relations has been an increase in public spending on physician services to allow the incomes of physicians to rise at a moderate rate without unduly taxing the fiscal capacity of provinces. Recent sharp increases in the average earnings of physicians, however, coupled with rising concerns over the proportion of health-care spending on provincial budgets, suggests that tensions may be heightened in the near future.

The incomes of physicians in Canada have received significant attention in health-policy discussions and for good reason. Since every dollar spent on health-care services ends up as someone's income, the "economic relationships ... between payment agency and provider are the heart of the whole system." Indeed, Canada's success in controlling the growth in physician fees is frequently credited with the divergent paths in health-care spending between Canada and the U.S. ${ }^{3}$ While the share of expenditures on physician services in the overall health-care budget has declined between 1987 and 2004, it has risen sharply since; moreover, physicians remain the focus of cost containment because of their role in controlling access to other health-care resources. ${ }^{4}$

1 M. L. Barer and R.G Evans "Riding North on a South-Bound Horse? Expenditures, Utilization and Incomes in the Canadian Health-care system," in Medicare at Maturity: Achievements, Lessons and Challenges (Calgary: University of Calgary Press, 1986), 53-164.

2 R.G. Evans, "Beyond the Medical Marketplace: Expenditure, Utilization and Pricing of Insured Health Care in Canada," in National Health Insurance: Can We Learn from Canada? ed. Spyros Andreopoulos (New York: John Wiley, 1975), 132.

3 J. Hughes, "How Well has Canada Contained the Cost of Doctoring?" Journal of the American Medical Association 265 (1991): 2347-2351; Jacalyn Duffin, "The Impact of Single-Payer Health Care on Physician Income in Canada, 1850-2005," American Journal of Public Health 101 (2011): 1198-1208.

4 As a percentage of total health-care spending, physician services fell from a high of 15.7 per cent in 1987 to a low of 13.1 per cent in 2004. It is forecast to be 14.2 per cent in 2012 (Canadian Institute of Health Information, National Health Expenditure Trends, 1975-2012, 2012, Table A.3.1.2). 
Attempts to document the earnings of physicians, however, have often produced conflicting results and interpretations. Whether the economic status of the profession as a whole has been improving, and whether there are significant differences across jurisdictions and specialties, remain the subject of some disagreement. The importance of these differences in perception is magnified in instances where the potential for conflict is greater, not only between governments and physician organizations, but also within provincial/territorial medical associations.

This paper examines several aspects of the incomes of physicians in order to consider the changing nature of government-physician relations. While in some ways it is a crude means of summarizing a complex relationship, it offers, from the perspective of the physician, an overview of the economic status of the profession while, from the perspective of provincial governments, it offers an important aspect of the attempt to control health-care costs. In common with Duffin, ${ }^{5}$ the paper takes the long view of physician earnings in order to place the current situation in historical context. In order to provide a consistent time series of the average income of physicians, data from a variety of sources is reconciled. The derivation of the data is outlined in detail in an appendix in order to focus the discussion in the main text on an interpretation of factors influencing earnings. A section of the paper unpacks this data to highlight two other features: average earnings by province, and by broad areas of specialization. Significant variation in incomes across provinces and specialties raises obvious concern about equity in remuneration, as well as implications for the allocation of physician resources. If relative fees or incomes are important in decisions about practice location, type of practice or area of specialization, they may be an important (and potentially neglected) lever for policy makers in human-resource planning. Given questions about the capacity of the Canadian health-care system to contain physician costs, we decompose the long-term trends in physician expenditures and incomes into their price (average fee) and quantity (utilization and physician stock) components. This exercise underscores the uniqueness of the experience with global budgets in the early 1990s as well as the changes that have occurred since 2003. The paper concludes by briefly considering the potential implications of recent events in Ontario and Alberta on the nature of physician-government relations in Canada in the future.

\section{HISTORICAL TRENDS IN PHYSICIANS' INCOMES, 1950-2010}

For the representative Canadian physician - earning the average income in the profession there has been a long-term, secular increase in income since 1950. It has, however, been a bumpy ride. Figure 1 displays the absolute income of the average physician in terms of 2010 constant dollars (or a measure of the purchasing power after adjusting for the impact of inflation) and Figure 2 indicates the relative income of physicians in comparison with the earnings of the average Canadian worker. Six distinct periods can be identified.

5 Jacalyn Duffin, "The Impact of Single-Payer Health Care on Physician Income in Canada, 1850-2005." 
FIGURE 1: AVERAGE NET INCOME, 1950-2010 (2010 CONSTANT DOLLARS)

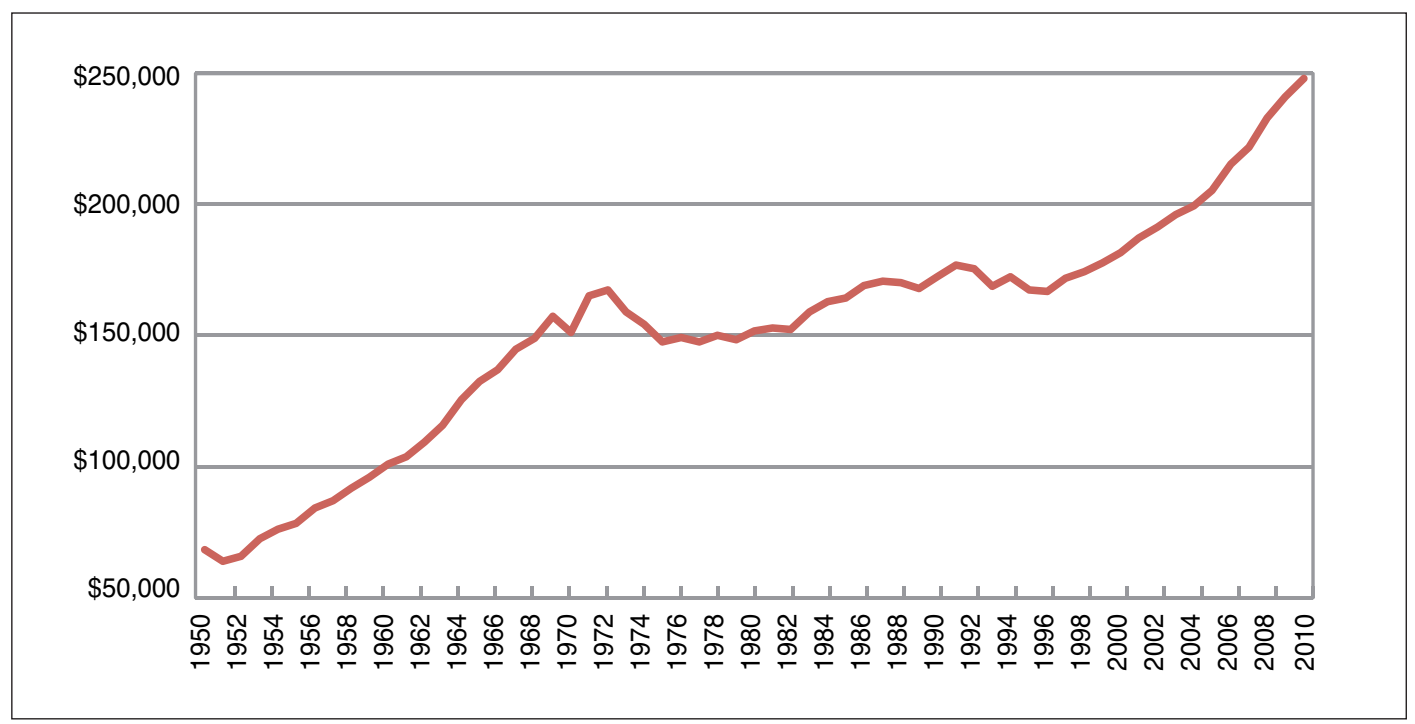

FIGURE 2: RELATIVE INCOME, PHYSICIANS VERSUS ALL WORKERS, 1950-2010

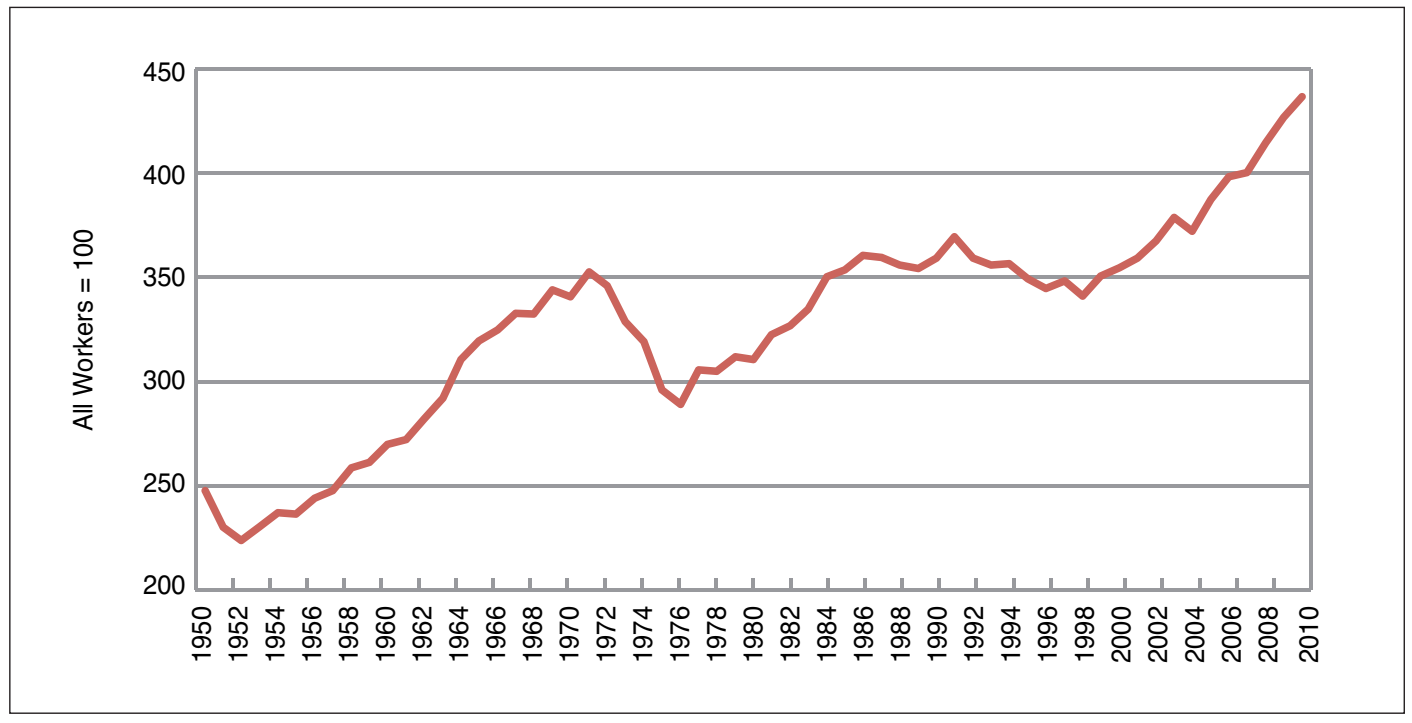

Sources: See appendix. The average income of all Canadian workers refers to full-time, full-year employees.

\section{The Golden Age of the Doctor, 1950-1971}

Following the Second World War, Canada's doctors enjoyed a remarkable increase in living standards. In particular, between 1950 and 1971, average net earnings rose from $\$ 68,424$ to $\$ 165,110$ (measured in terms of 2010 dollars). This was not simply a reflection of growing prosperity throughout the economy, as the income of physicians increased from 248 per cent of the earnings of the average Canadian worker to 353 per cent of the average Canadian worker's earnings. 
Higher incomes occurred within an institutional setting of physician-sponsored insurance, plans that provided roughly half of the Canadian population with comprehensive, first-dollar, community-rated coverage. The provincial medical association established the fee schedule, largely as a guide to the maximum rate that should be charged, and physicians were free to discount off the schedule according to a patient's income and other circumstances. If the insurer encountered an excess of payments over revenue, a retroactive reduction in fees would occur, but was usually followed by an increase in premiums. ${ }^{6}$

In light of the opposition from physician organizations to public health insurance, ${ }^{7}$ it is somewhat surprising that the implementation of provincial plans in the late 1960s and early 1970s was accompanied by dramatic increases in physician incomes, the result of increases in fee schedules, utilization and the collections ratio. ${ }^{8}$ Evans speculated that public insurance plans would not effectively constrain costs for two reasons: 1) federal-provincial cost-sharing reduced incentives on the part of provincial governments to keep costs down (since they bore only half of the marginal cost); and 2) the reluctance of governments to encroach upon the autonomy of physicians in the area of fee setting. Most provinces simply adopted the existing fee schedule of the provincial medical association, and reimbursed physicians at a 10-per-cent discount on the grounds that the collection rate (or the ratio between actual and list prices) effectively increased to 100 per cent. Within this context, "health providers at all levels, from physicians down through hospital janitors, seemed to have revised their income aspirations upward in response to the observation that the payment process was open-ended ... And so it has turned out that the single most prominent influence of health insurance in Canada has been to increase the earnings of health providers."

\section{Retrenchment on Fees, 1971-1979}

Bountiful times under public insurance proved to be short-lived. Fee schedules in most provinces remained unchanged for several years and, coupled with the high inflation rates of the "oil crisis" era, the real value of fees tumbled by 20 to 25 per cent. Increased utilization was unable to compensate fully for the decline in fees, such that between 1971 and 1975, the average income of a physician fell from $\$ 165,110$ to $\$ 148,539$. More remarkable was the decline in the relative income, from 353 per cent of the average Canadian worker, to 312 per cent.

6 C. David Naylor, Private Practice, Public Payment: Canadian Medicine and the Politics of Health Insurance, 1911 1966 (Kingston: McGill Queen's University Press, 1986).

7 Regarding the long-term implications of the doctors' strike in Saskatchewan, see: Gregory P. Marchildon and Klaartje Schrijvers, "Physician Resistance and the Forging of Public Healthcare: A Comparative Analysis of the Doctors' Strikes in Canada and Belgium in the 1960s," Medical History 55 (2011): 203-22.

8 The collections ratio is the ratio between the fee received by the physician and the scheduled fee. Prior to public health insurance, physicians discounted off the fee schedule depending upon a patient's economic circumstances and/or insurance coverage.

9 R.G. Evans, "Beyond the Medical Marketplace: Expenditure, Utilization and Pricing of Insured Health Care in Canada," 133. 
The decline in incomes took many observers by surprise. Evans ${ }^{10}$ acknowledged that the willingness of governments to leave the setting of fees as the prerogative of medical associations and merely "pay the bills," quickly disappeared, to be replaced by a de facto negotiation process between the jurisdiction and its medical association. Since the importance of maintaining autonomy over fee setting (as well as the ability to price discriminate) was the major basis for the Canadian Medical Association's opposition to public insurance, ${ }^{11}$ it was conceded that: "In retrospect, it appears that [physicians, in opposing public health insurance] made a very clear and accurate assessment of where their interest lay." 12

For this reason, "extra billing" and "opting out" were perceived to be important safety valves in physician-government relations. Although regulations varied across the country, all provinces allowed physicians some recourse to extra billing (charging patients in excess of what the provincial insurance plan would pay) or opting out of the provincial plan in order to bill patients directly. In 1972, Ontario introduced "practice-streaming" provisions that required physicians to have their entire practice either "in or out" of public insurance coverage. The Ontario Medical Association was more strongly opposed to practice streaming than to medicare: the former preserved the right to set fees but removed the ability to price discriminate (or bill the provincial plan in the case of poor patients, and directly bill wealthier patients a higher fee). Some 13.5 per cent of Ontario's physicians opted out in October 1972, but this number gradually declined..$^{13}$ The prevailing view is that, outside of Alberta and Ontario, extra billing and opting out were never very significant and, on a national level, it never amounted to more than five per cent of total physician remuneration. ${ }^{14}$

The lull in the upward march of incomes is attributed to several factors. One is that the income aspirations of physicians were "somewhat muted" and their militancy "muffled by money" in light of the rapid gains of the 1960s. A second presumed factor is that physicians had yet to organize effectively for the fee-negotiation process. A third is the lack of public sympathy for the economic plight of doctors, which undermined their bargaining power.

${ }^{10}$ R.G. Evans, "Beyond the Medical Marketplace: Expenditure, Utilization and Pricing of Insured Health Care in Canada."

11 C. David Naylor, Private Practice, Public Payment: Canadian Medicine and the Politics of Health Insurance, 19111966.

12 M. L. Barer, R.G. Evans and R. Labelle, The Frozen North: Controlling Physicians Costs through Controlling Fees - The Canadian Experience, Contractor Document, Health Program, Office of Technology Assessment, U.S. Congress. Washington, 1985: 1-17.

13 A. D. Wolfson and C. Tuohy, Opting out of Medicare: Private Medical Markets in Ontario (Toronto: Ontario Economic Council, 1980).

14 M. L. Barer, R.G. Evans and R. Labelle, The Frozen North: Controlling Physicians Costs through Controlling Fees - The Canadian Experience, 1-34. 
Any pent up demand for higher incomes that may have existed was effectively suppressed by the Anti-Inflation Board (AIB) of 1975-1978. The Canadian government imposed wage controls on all federal government employees, private-sector employees in larger firms and self-employed professionals. Voluntary compliance on the part of all but two provinces extended coverage to provincial public employees as well. Maximum wage and fee increases were set at eight per cent in the first year, six per cent in the second, and two per cent in the third (with some adjustments for productivity) to accord with the government's inflation targets. For self-employed professionals, net income could not increase by more than $\$ 2,400$ per year. A concern about the application of controls was the redistribution that might occur because some wage increases were easier to monitor than others. Physician fee schedules, in this respect, were easy targets and subject to the approval of the AIB. While this might have resulted in physicians falling behind other self-employed professionals, they actually benefited from the high visibility of their fee negotiations because it exempted them from other controls. Reid $^{15}$ found that: "For the vast majority of physicians the AIB's influence was felt only through the Board's influence on provincial fee negotiations ... [and] physicians fared better than other professional groups since they were not subject to the $\$ 2,400$ per year limit which applied to most professionals."

\section{Rising Utilization Rates, 1979-1991}

During the 1980s, there was a steady increase in the income of physicians from $\$ 148,539$ to $\$ 177,017$ by 1991 . The magnitude of this increase can only be appreciated in the context of general economic conditions marked by increasing fiscal difficulties in most provinces and stagnant incomes for Canadian workers. By the end of the decade, the profession had more than restored the purchasing power it lost during the 1970s and was once again enjoying a standard of living roughly four times that of the average worker.

If the provinces proved more resilient in fee negotiations than anticipated, Evans' concern expressed in 1975 about their ability to control utilization and, therefore, cost, appeared prescient: "The role of national health insurance may simply have been to relax further any market constraint on how physicians manipulate utilization to generate income."16

The one significant institutional change in the period was the introduction of the Canada Health Act in 1984, which effectively banned extra billing by financially penalizing any province that permitted the practice to continue after 1987. While accommodating legislation was passed with little rancour in most provinces, the Ontario Medical Association called for a withdrawal of services to protest the introduction of Bill 94. A 25-day walkout ensued, although the extent of physician participation is unclear. ${ }^{17}$ While this had no immediate impact

\footnotetext{
15 Frank Reid, "Effect of Incomes Policy on Health Industrial Relations in Canada," in Industrial Relations and Health Services, eds. Amarjit Singh Sethi and Stuart J. Dimmock (New York: Taylor and Francis, 1982): 319.

16 R.G. Evans, "Beyond the Medical Marketplace: Expenditure, Utilization and Pricing of Insured Health Care in Canada," 162.

17 There is no noticeable drop in the average income of Ontario's physicians in 1986 as would be implied by a widespread withdrawal of services for nearly a month.
} 
on incomes (indeed, in many provinces a special percentage increase in fees was made as compensation for lost extra-billing rights) it is credited with intensifying government-physician conflict. Meslin ${ }^{18}$ suggests that the walkout by Ontario's physicians, by failing to convince either the government or the public that their claim to reasonable compensation was on an equal moral plane with the public's right to health care, did long-term harm by undermining their relationship with the public.

\section{Global Budgets, 1991-1996}

The apparent inability of provinces to control increases in utilization was cast into sharp relief by the fiscal problems experienced in most provinces during the early 1990s. Rising provincial health-care costs, coupled with declining federal transfers, was a major contributor to growing budget deficits. The result was a "stampede" on the part of provincial governments towards the adoption of expenditure controls on physician services.

Global budgets were designed to reduce utilization by fixing the total amount of money available for reimbursement. In the event that utilization exceeded a prescribed limit, some of the liability was transferred to physicians by way of a reduction in fees. The most common way in which this was implemented among Canada's provinces was to place a limit on the total funds available for payments to physicians, with any overrun recouped through prospective or retrospective reductions in fees. In some cases, this was complemented by restrictions on the earnings of individual physicians: by 1992, all six provinces east of Manitoba were experimenting with non-linear compensation schemes for physicians, wherein practitioners billing above a certain threshold received only a percentage of the normal fee. ${ }^{19}$ In Ontario, for instance, two thresholds were introduced in 1991. Billing claims between $\$ 400,000$ and $\$ 450,000$ were paid at only 67 per cent of the normal fee, and those above $\$ 450,000$ were reimbursed at only 33 per cent. Two years later, annual global budget caps were added: if total billings exceeded the cap, the money was recouped through fee reductions in the subsequent year. In 1995, still harsher measures were adopted with the unilateral imposition of specialtyspecific thresholds and higher discounts on fees when thresholds were exceeded. ${ }^{20}$

The timing, duration and severity of expenditure controls varied with the enthusiasm for deficit reduction in each province; however, their impact on the income of physicians at an aggregate level was apparent by the early 1990s: average incomes fell from $\$ 190,634$ to $\$ 179,714$ between 1991 and 1996 and the decline in relative income was of a similar proportion.

18 Eric M. Meslin, "The Moral Cost of the Ontario Physicians' Strike," Hastings Centre Report 17, 4 (1987) 11-14.

19 Jeremiah Hurley, Robert Card and Laurie Goldsmith, "Physician Expenditure Cap Policies for Canada: Development, Design and Implications for Analysing their Effects," Final Report, National Health Research and Development Program, 1997. For a summary of expenditure controls by province, also see: Jonathan Lomas et al., "Paying Physicians in Canada: Minding our Ps and Qs," Health Affairs 8 (1989): 80-102; M. L. Barer, J. Lomas and C. Sanmartin, "Re-Minding Our Ps and Qs: Medical Cost Control in Canada," Health Affairs 15 (1996): 216-34; Steven J. Katz et al., "Physician Relations in Canada: Shooting Inward as the Circle Closes," Journal of Health Politics, Policy and Law 22 (1997): 1413-31.

20 Catherine Dowdall and Lorna Ramchandar, "The Application of Physician Billing Thresholds in Ontario and Across Canada," Ontario Medical Review (September 1999): 17-21. 
The ability of expenditure controls to do just that - control expenditures - is beyond dispute, at least in the short-term. Provincial authorities assumed a more aggressive stance in collective bargaining, with some adopting a "take-it-or-leave-it" approach, ${ }^{21}$ while others simply imposed a fee settlement. Such unilateral action reflected an apparent inequality in bargaining power, with provincial medical associations lacking the de facto power to mobilize an effective withdrawal of services in support of income demands. Exercising this unilateral power, however, raised several concerns about the long-term harm not only to government-physician relations, but also to physician-physician relations, inter-governmental co-operation and even the public interest.

In the case of government-physician relations, expenditure caps marked a further encroachment upon physicians' jealously guarded professional autonomy. Evans ${ }^{22}$ identifies the reciprocal obligations inherent in the nature of the licensing and regulatory framework. In return for the economic power that derives from having exclusive jurisdiction over specific medical procedures, physicians as a profession are expected to govern themselves in such a fashion as to protect the interest of patients and the public generally. While the government's role in setting fees is difficult to dispute, direct control over utilization is perceived to be an intrusion upon clinical autonomy and the patient-physician relationship. Despite efforts to elicit cooperation through joint management structures, the danger is that greater confrontation may undermine the agency relationship between governments and physicians.

Physician-physician relations encountered equally serious challenges from global budgeting. By establishing a fixed pool of money from which physicians were to be paid, incentives were created for strategic behaviour on the part of individual physicians at a time when greater cooperation was required.$^{23}$ In the case of Nova Scotia, the absence of appropriate mechanisms for co-ordinated behaviour and to monitor "fee grabbers" led to an erosion of trust and goodwill. This was accompanied by a "downward spiral" of lower fees, prompting efforts by individual physicians to increase utilization, with aggregate utilization increases leading to further fee reductions and even greater incentives for individual physicians to increase utilization. ${ }^{24}$ In many instances, global caps exacerbated existing internal divisions within provincial associations - between urban and rural physicians and between specialties - over the distribution of income. ${ }^{25}$ Arguably, the government does benefit from internal divisions within the medical association to the extent that it undermines physician solidarity and, therefore, bargaining power. But it also carries with it an element of uncertainty, particularly if traditional mechanisms of professional self-governance are undermined. Moreover, the loss of morale and professional commitment might also have serious implications for the quality of care.

21 R. B. Deber, S.L. Mhatre and G.R. Baker, "A Review of Provincial Initiatives," in Limits to Care: Reforming Canada's Health System in an Age of Restraint, eds. A.G. Blomqvist and D.M. Brown (Toronto: C.D. Howe Institute, 1994), 99.

22 R.G. Evans, Price Formation in the Market for Physician Services in Canada, 1957-1969, Information Canada, 1972.

23 Jeremiah Hurley and Robert Card, "Global Physician Budgets as Common-Property Resources: Some Implications for Physicians and Medical Associations," Canadian Medical Association Journal 154 (1996): 1161-68.

24 Jeremiah Hurley, Jonathan Lomas and Laurie J. Goldsmith, "Physician Responses to Global Physician Expenditure Budgets in Canada: A Common Property Perspective," Milbank Quarterly 75 (1997) : 343-65.

25 Steven J. Katz et al., "Physician Relations in Canada: Shooting Inward as the Circle Closes." 
Government-government relations also suffered from beggar-thy-neighbour approaches. Implementation of one recommendation of the Barer-Stoddart report ${ }^{26}$ (commissioned by the provincial deputy ministers of health), to reduce medical school enrolment by 10 per cent and further restrict the number of international medical graduates, was an important step towards a national strategy for managing the growth in physician services. But this spirit of interprovincial co-operation was subverted by subsequent efforts in Ontario to restrict billing privileges to graduates of the province's own medical schools, and British Columbia undertook similar measures for migrating physicians. ${ }^{27}$

Finally, in one important respect, global expenditure caps were in conflict with the goal of equal access to health care by aligning incentives for physicians and governments to de-insure procedures. Redefining some services as no longer "medically necessary," so as to remove them from public insurance coverage, obviously reduces the pressure on government budgets while giving physicians autonomy over billing patients directly and outside of the purview of expenditure caps.

\section{Dismantling Expenditure Caps, 1997-2001}

Global caps were an extraordinary, and temporary, measure to address provincial budget concerns. With the gradual unwinding of caps in each province, the average income of physicians rebounded, reaching $\$ 187,134$ by 2001 . Alberta led the way with a negotiated settlement in 2000 that included a 21-per-cent average fee increase over two years. ${ }^{28}$

One interpretation of the recovery in earnings underscores the strength of the physiciangovernment relationship. As the financial pressures on provincial governments eased, restrictions on expenditures were removed, previous norms of negotiating over increases in the fee schedule were resumed, and physicians were compensated for the income lost during the period of restraint. In short, the income-determination process was sufficiently flexible to accommodate the unusual financial circumstances of the early 1990s without breaching the spirit of the long-term, implicit agreement over the rate of growth in incomes.

Figure 3 offers supports for this view. It displays the trend in average income between 1975 (the low point in incomes following the adoption of medicare) and 1991 (prior to the full impact of global caps). Over the 16-year period, average income rose by one per cent a year in real terms. Extrapolating this forward highlights not only how far behind this trend line physicians' incomes fell between 1991 and 1996 but, more strikingly, how quickly they recovered afterwards. Indeed, by 2001, average income had returned to the long-term trend established since the mid-1970s.

26 M. L. Barer and G.L. Stoddart, Toward Integrated Medical Resource Policies for Canada, Federal/Provincial/ Territorial Conference of Deputy Ministers of Health, Ottawa 1991.

27 In an effort to discourage physicians from locating in the "wrong places," Ontario sought a 75-per-cent fee reduction over five years for new graduates in family medicine, paediatrics, and psychiatry who established practices in areas that the Ministry of Health judged to be "over serviced." When this was met with a threat of withdrawal of services, the plan was abandoned in favour of a prohibition on physicians educated outside of the province from entering feefor-service practice (R.B. Deber, S.L. Mhatre and G.R. Baker, "A Review of Provincial Initiatives," in Limits to Care: Reforming Canada's Health System in an Age of Restraint, eds. A.G. Blomqvist and D.M. Brown (Toronto: C.D. Howe Institute, 1994), 101. 
If this signalled a return to the status quo in terms of the level of remuneration, it was accompanied by a ratcheting up in the level of confrontation. Sibbald ${ }^{29}$ suggests that there was a "new wave" of militant doctors, and reports drawn from the Medical Post indicate that "doctor activism" assumed new dimensions ${ }^{30}$ Emergency-room physicians working to rule to protest rates of pay and on-call requirements, rotating strikes and phased-in withdrawals of service, and hospital-based physicians threatening to walk out all increased with alarming frequency. A high point was reached in 1998. Obstetricians in Alberta, Manitoba and Quebec, following a precedent set by their colleagues in Ontario two years earlier, stopped taking new prenatal patients to protest low delivery fees. Physicians in rural, northern B.C. won a pay increase and improved working conditions after resigning their hospital privileges and forcing the closure of regional hospitals. The technique of voluntary office closures (or "reduced activity days") to protest funding shortages - despite public opposition - proved effective in northern B.C. and quickly spread to Alberta and Quebec. In Manitoba, attending family physicians at four community hospitals withdrew their services. In Saskatchewan, demands for additional payments for on-call family physicians in rural areas led to a withdrawal of services. In Quebec, where global expenditure caps remained in place until 2000, general practitioners (GPs) threatened a full-scale withdrawal of services in support of their fee demands. In 2001, the relative quietude in Atlantic Canada abruptly ended with a full-scale walkout by New Brunswick physicians, followed a year later by a 17-day walkout by physicians in Newfoundland and Labrador.

29 Barbara Sibbald, "In Your Face: A New Wave of Militant Doctors Lashes Out," Canadian Medical Association Journal 158 (1998): 1505-9.

30 From the Medical Post: "Doctor activism," 39, 40 (November 4, 2003): 58; Robert Walker, "Alberta's obstetricians to strike January 1 unless delivery fee rise: want 64\% fee increase," 34, 18 (May 12, 1998): 2; Louise Gagnon, "Quebec ob/gyns settle: government steps in to end threat of strike," 34,6 (February 10, 1998); Myron Love, "Manitoba's obstetric MDs to stop delivering: protest over low fees spreading out from Winnipeg," 34, 21 (June 5, 1998): 2; "Ontario specialists put strike on hold, for now," 32, 32 (September 24, 1996): 2, 51; Matt Borsellino, "Interior doctors at work after winning 22-week-long fight," 34, 23 (June 23, 1998): 5; Matt Borsellino, "Protests Spread: BC Doctors Most Active but Alberta and Quebec MDs Enter the Fray," 34.12 (March 31 1998): 1; Robert Walker, "Doctors take action: Alberta government bill prompts physicians to close work office, work to rule," 34,14 (April 14, 1998); Robert Walker, “Alberta rural MDs close offices for a day in fee protest," 34, 25 (July 7, 1998): 2; Matt Borsellino, "BCMA's reduced activity days flayed by media," 34, 10 (March 17, 1998): 2; Matt Borsellino, "BC doctors resolved despite poll slamming fee demands," 34, 14 (April 14, 1998): 1; Matt Borsellino, "BC doctors plan more office closures: reduced activity days will total 12 by fiscal year-end," 34, 26 (July 21, 1998); David Square, "60 FPs stop work in Manitoba hospitals in pay fight," 34, 7 (February 17, 1998): 2; Deana Driver, "SMA trying to settlement payment plan for on-call physicians," 34, 19 (May 19, 1998): 39; Louise Gagnon, "Quebec GPs gear up for strike,” 34, 20 (May 26, 1998): 5; Susannah Benady, “'If talks break down we'll strike,' Quebec FPs threaten," 36, 7 (February 15, 2000): 5; Ann Graham-Walker, "East-Coast doctors stronger after strike: job action in New Brunswick may help other provinces with contract negotiations," 33, 3 (January 23, 2001): 1,71. 
FIGURE 3: NET REAL INCOME, ACTUAL VERSUS ESTIMATED TREND, 1975-2010

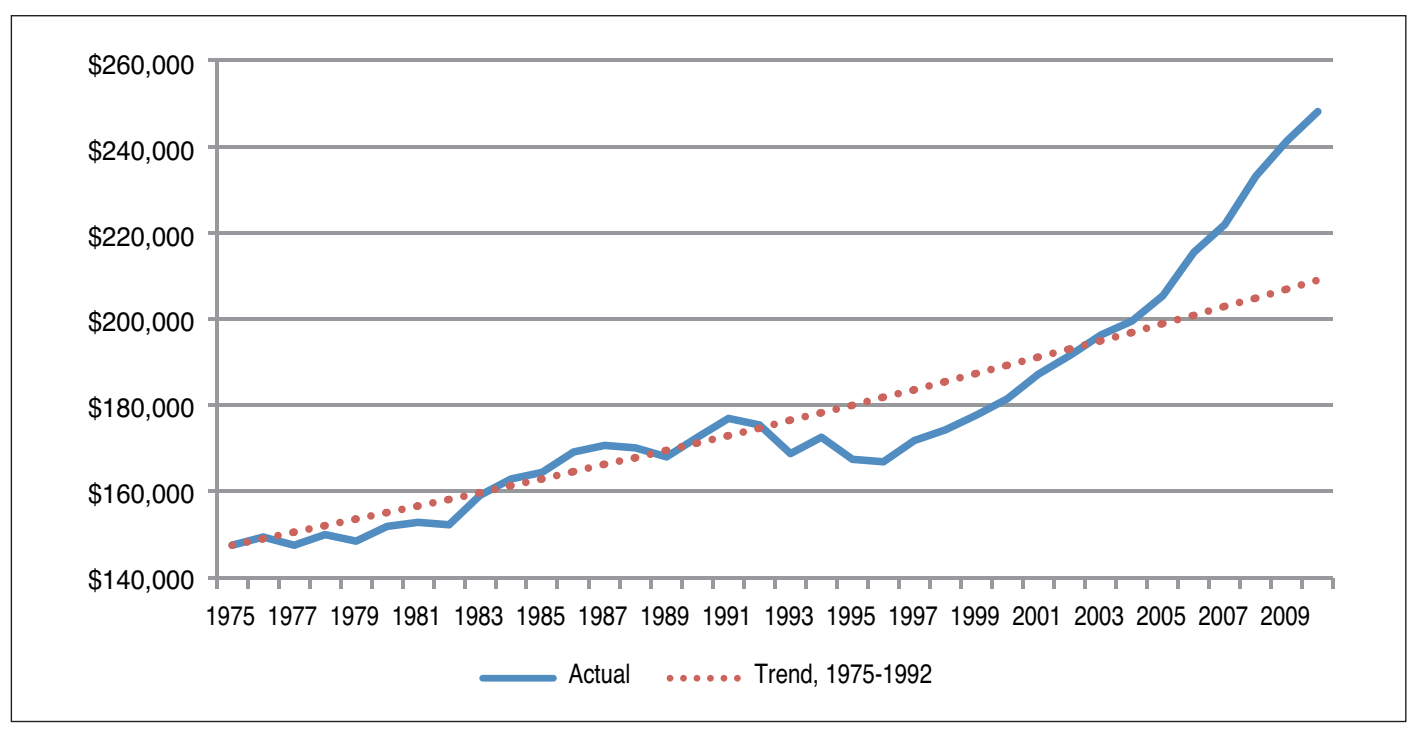

\section{Peaceful Accommodation, 2001-2010}

Increasing conflict between 1996 and 2001 and trends in earnings after 2001 suggests that there was not merely a return to business as usual in the pattern of fee negotiations that existed prior to the implementation of global caps. Since 2001, the income of physicians has increased at its fastest rate since the introduction of public insurance, rising from $\$ 187,134$ to $\$ 248,113$ in 2010. Since the removal of global expenditure caps in 1996, average incomes have risen by nearly 50 per cent.

Some profound changes occurred, beginning in the mid-1990s, to affect the political dynamic in the negotiation process. The perennial battleground over whether there were too many or too few physicians abruptly swung towards the perception of a shortage. ${ }^{3 l}$ Where the underservicing of rural and remote areas had been a persistent concern, many urban residents were now experiencing difficulty in finding a family physician. ${ }^{32}$ Increasing attention to waiting lists, "hallway medicine" and de-insured services undermined the provinces' claim to having reduced health-care costs by attacking unnecessary utilization. ${ }^{33}$ Fears that an aging population would increase demand for physician services were magnified by demographic changes in the physician workforce that included an aging stock and a rising proportion of women with a tendency to engage in fewer hours of direct patient care. ${ }^{34}$ One response was to expand the

31 Benjamin Chan, From Perceived Surplus to Perceived Shortage: What Happened to Canada's Physician Workforce in the 1990s? (Ottawa: Canadian Institute for Health Information, 2002).

32 Statistics Canada, "Access to a regular medical doctor, 2011," Health Fact Sheets, Catalogue number 82-625-XWE, 2012.

33 Counteracting this tendency to a reduced supply of physician services was a much lower outflow of Canadian-trained physicians to the United States due, in part, to a declining earnings gap and institutional mechanisms by HMOs in the United States to restrict the demand for physician services (Jacalyn Duffin, "The Impact of Single-Payer Health Care on Physician Income in Canada, 1850-2005.").

34 S.H. Jeon and J. Hurley, "The Relationship between Physician Hours of Work, Service Volume and Service Intensity," Canadian Public Policy 33, supplement (2007): 17-30; T. Crossley, J. Hurley and S. Jeon, "Physician Labour Supply in Canada: a Cohort Analysis," Health Economics 18 (2009): 437-56; cf. C. P. Herbert et al., "Ending the Sexist Blame Game," Canadian Medical Association Journal 178, 6 (2008): 659. 
number of seats in Canadian medical schools and to improve the access of international medical school graduates to the physician workforce. Together, these factors enhanced the legitimacy of physicians' arguments that underfunding was rife throughout the system.

Suddenly physicians, not the state, were seen as champions of the public's access to health care.

\section{Summary}

A central feature to maintaining relatively peaceful physician-government relations in Canada since the introduction of public insurance has been a steady increase in the average income of physicians. This upward path has been interrupted on only two occasions: 1) in the early 1970s, shortly after the introduction of public insurance, when fees fell dramatically behind the rate of inflation; and 2) in the early 1990s, when all provinces adopted some form of global expenditure caps in an effort to control utilization.

Two other related factors contributed to the changing nature of physician-government conflict. Within the narrowly defined context of collective bargaining over fees, physician organizations demonstrated increasing sophistication in collective actions to support their income demands. If the lesson from industrial action in the 1980s was that the strike weapon was ineffective in obtaining physician compliance and in rallying public support, experimentation with alternative measures proved more successful in the 1990s. Province-wide rotating office closures and study sessions, or short-term withdrawals of services by specific groups of specialists or in specific regions, bolstered negotiating demands by displaying the importance of physicians in the health-care delivery system without undermining the patient-physician relationship as a full-scale strike had done in the past.

More generally, however, negotiations over remuneration have largely been confined to the political sphere. The relative bargaining strength of each party rests upon public support for rival claims as to who better safeguards the public health-care system. Where the perception has been that excessive utilization rates have led to an unwarranted escalation in health-care costs, there has been public support for provincially imposed constraints on the incomes of physicians. In contrast, physicians have marshalled greater public support for increased healthcare expenditures and higher incomes where there are concerns that underfunding has led to a shortage of family practitioners or long waiting lists for surgical procedures.

\section{EARNINGS BY PROVINCE AND SPECIALTY}

Trends in the average earnings of Canadian physicians mask the range of experiences among individual physicians. We consider two factors - province of practice and broad area of specialization - not with the intention of providing an exhaustive survey, but rather to offer some observations on the general patterns. 


\section{Earnings by Province}

Canada does not have a single health-care system, but rather, one system in each province and territory. Despite varying fiscal circumstances and labour-market conditions in each province, one would expect the migration of physicians between provinces to lead to a convergence in rates of remuneration. The decision to move between provinces depends upon both economic (relative fees and practice patterns) and non-economic factors, but one would expect a sufficient degree of economically motivated migration to maintain a single, national physicianlabour market. ${ }^{35}$

Figure 4 displays the average gross income of physicians in each province for 2011 based upon National Health Expenditure data, with the solid line indicating the national average. The differences between provinces are significant, ranging from $\$ 296,241$ in Quebec to $\$ 470,036$ in Ontario. In general, incomes tend to be higher in Ontario and the Prairie provinces, and relatively low in British Columbia and Quebec. Several factors may explain these differences such that caution must be exercised in interpreting the data. First, it may depend on the composition of the physician workforce: provinces with a greater percentage of primary-care physicians (who earn less than specialists) will tend to have lower average incomes (see Figure 7). Second, since the data refer to income before expenses, part of the variation across provinces may be due to the cost of maintaining a practice. The Canadian Institute for Health Information ${ }^{36}$ notes that expenses tend to be higher in Ontario and the western provinces compared to Quebec and the Atlantic provinces. Third, gross incomes will tend to be lower in provinces with a relatively large proportion of physicians working on a salaried basis, such as in Quebec.

Casual inspection of Figure 5, which displays the trends in gross earnings by province between 1978 and 2011, suggests that there is a tendency for earnings to converge. On rare occasion, the average gross income in a province has risen 20 per cent above or 20 per cent below the national average. Quebec may be the exception which proves the rule. If language barriers restrict physician mobility into and out of Quebec, it may provide for greater monopsony power on the part of the provincial government in bargaining over fees. Figure 7 displays the co-efficient of variation of average incomes by province between 1978 and 2011. Although no secular trend is evident, it might be inferred that incomes across provinces tended to converge during the period of lower income growth in the 1990s.

\footnotetext{
35 M. Benarroch and H. Grant, "The Inter-Provincial Migration of Canadian Physicians: Does Income Matter?" Applied Economics 36 (2004): 2335-45; Benoit Dostie and Pierre Thomas Leger, "Self-Selection in Migration and Returns to Unobservables," Journal of Population Economics 22 (2009): 1005-24; James Ted McDonald and Christopher Worswick, "The Migration Decisions of Physicians in Canada: The Roles of Immigrant Status and Spousal Characteristics," Social Science and Medicine 75 (2011): 1581-8.

36 Canadian Institute for Health Information (CIHI), Analytical Bulletin: Physician Expenditures, 1, 2004.
} 
FIGURE 4: AVERAGE GROSS INCOME OF PHYSICIANS, BY PROVINCE, 2011 (CURRENT DOLLARS)

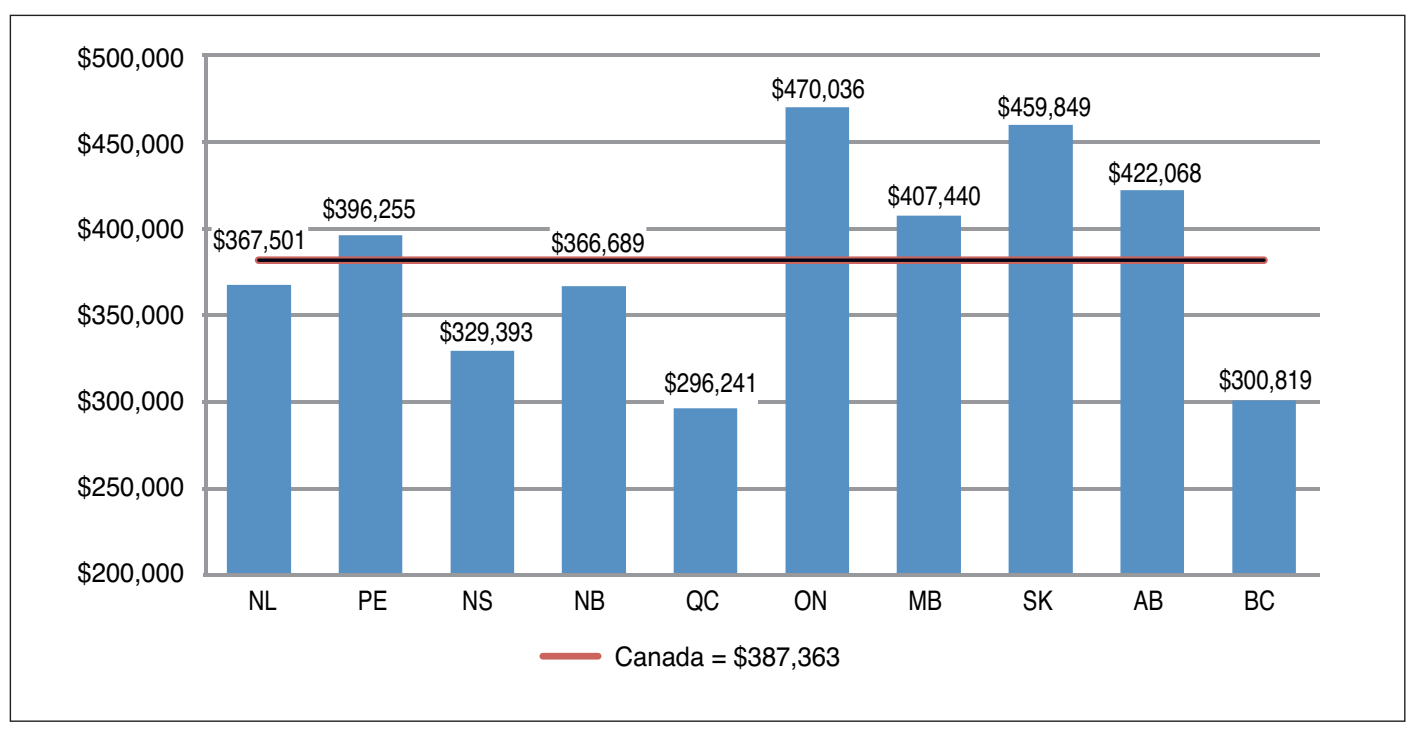

Source: Derived from Canadian Institute for Health Information, National Health Expenditure Trends, 1975-2012 (Ottawa, 2012).

FIGURE 5: INDEX OF RELATIVE EARNINGS BY PROVINCE, 1978-2011 (CANADA = 100)

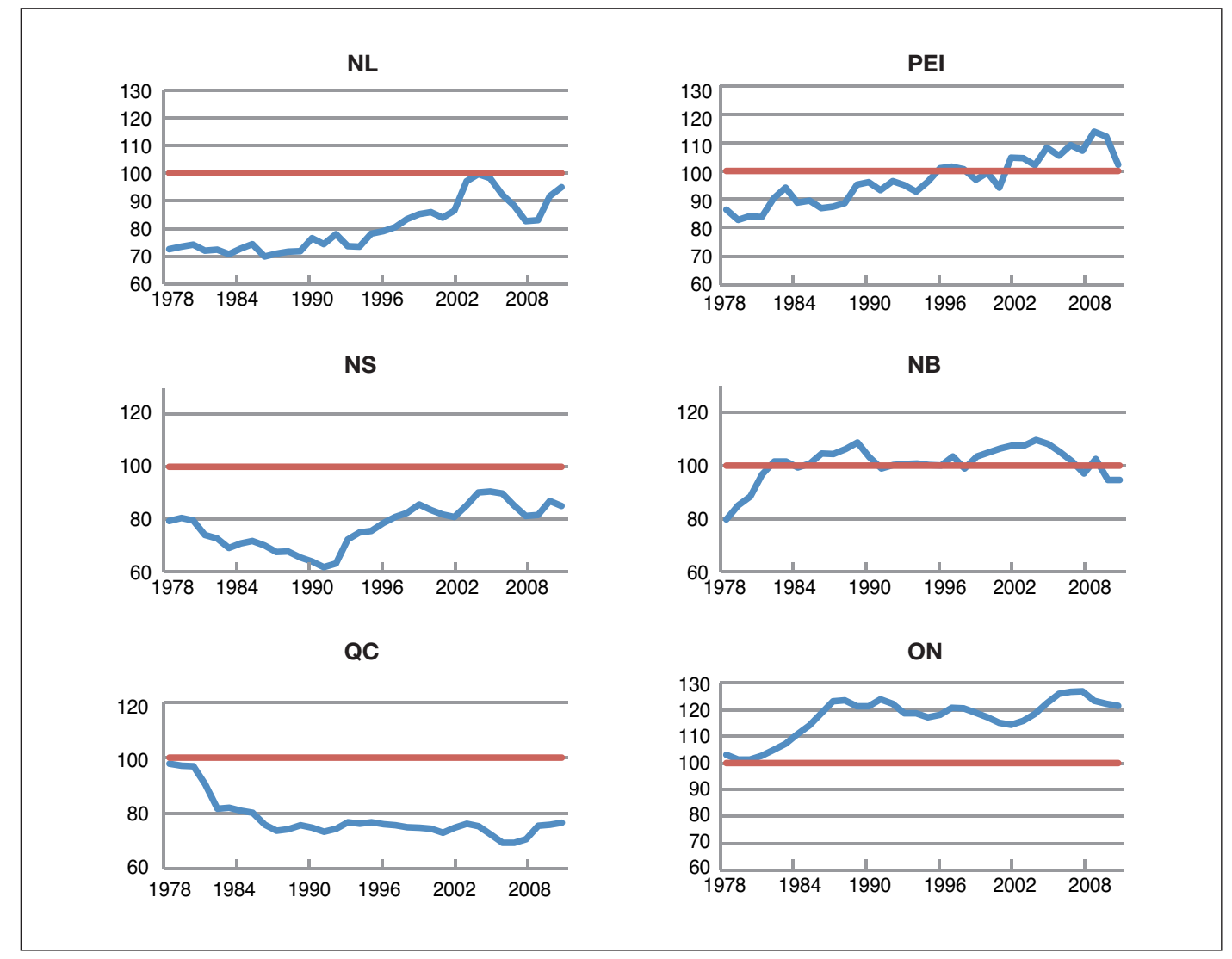


FIGURE 5 (CONT'D): INDEX OF RELATIVE EARNINGS BY PROVINCE, 1978-2011 (CANADA = 100)

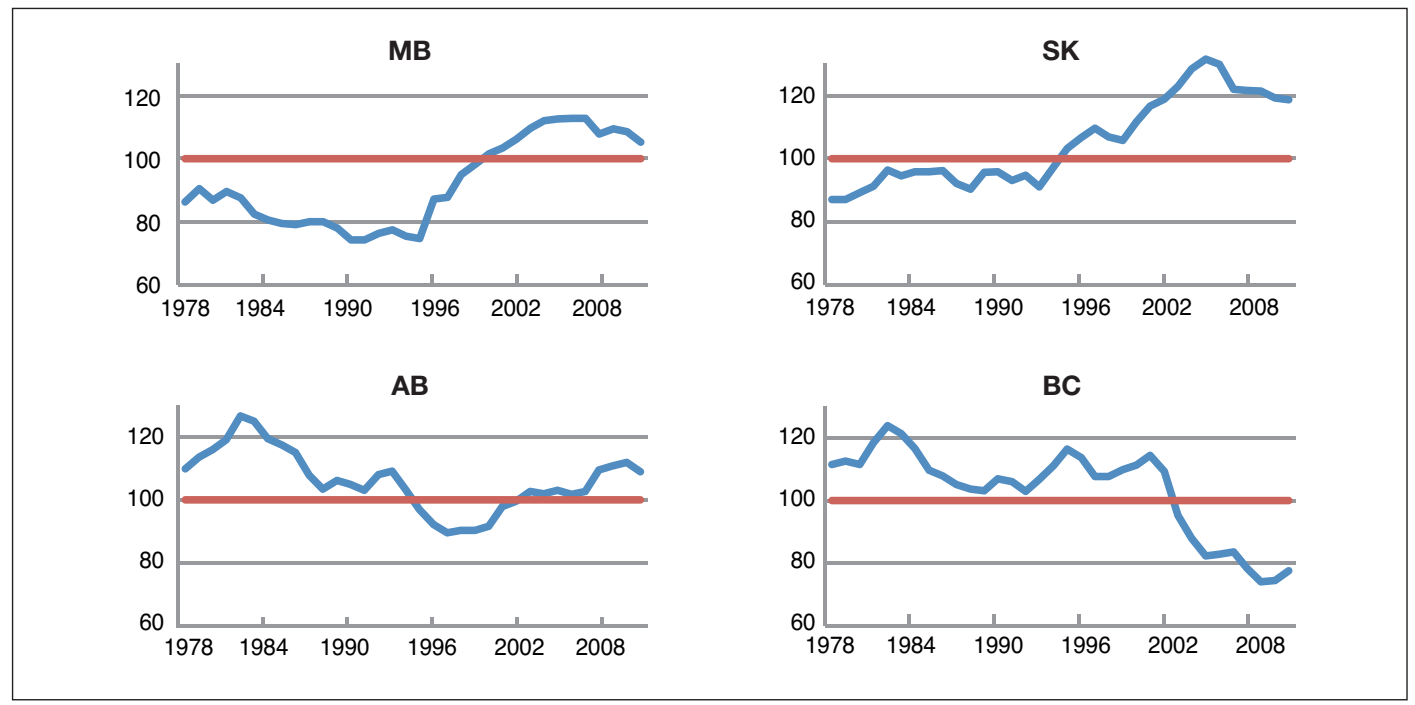

\section{FIGURE 6: CO-EFFICIENT OF VARIATION, AVERAGE INCOME BY PROVINCE, 1978-2011}

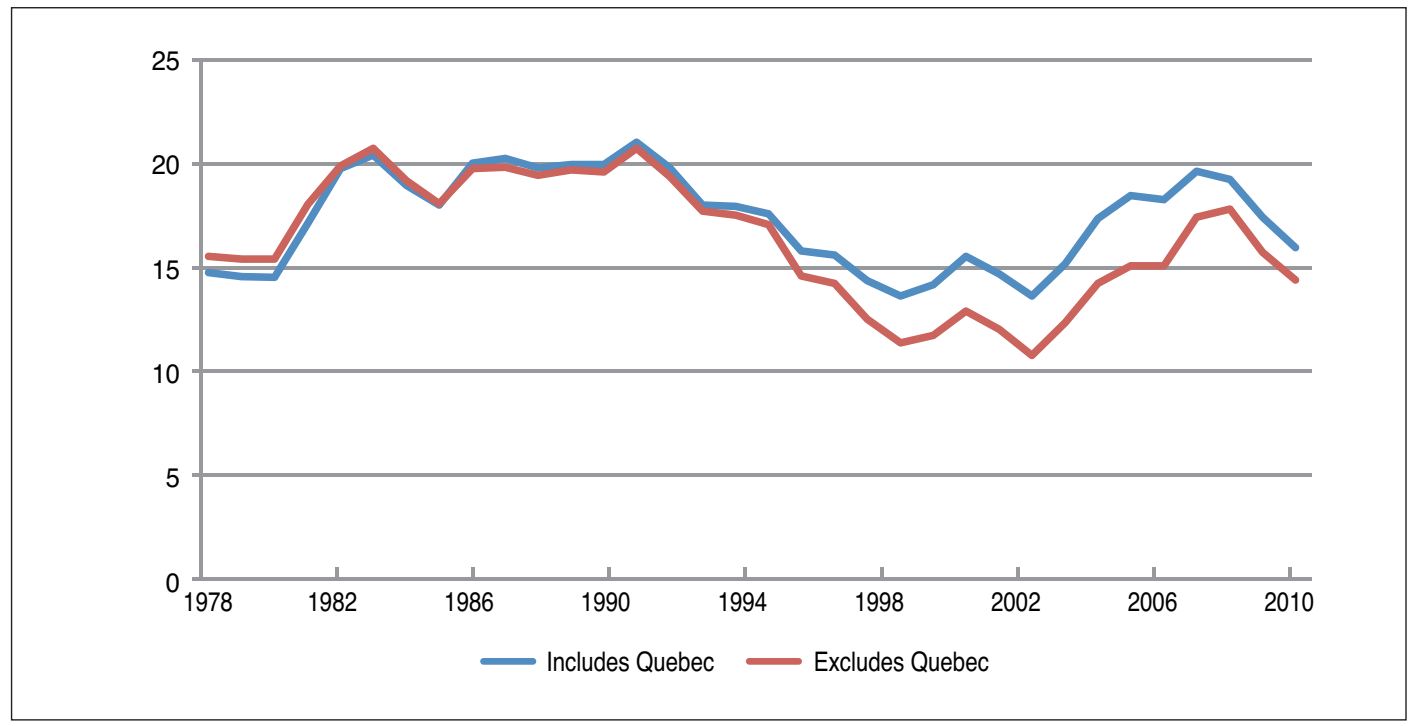

Source for Tables 5 and 6: Derived from Canadian Institute for Health Information, National Health Expenditure Trends, 1975-2012 (Ottawa, 2012).

\section{Earnings by Specialty}

A peculiarity of the negotiating process between provincial governments and medical associations is that the distribution of overall fee increases across specific medical-fee items has historically been left largely to the medical association. This is achieved through a "bear pit" session among representatives of different specialty groups with the procedure "explicitly viewed by physicians as an income allocation process., ${ }^{37}$ 
Modification to relative fees is a politically sensitive issue for both governments and medical associations. By ceding responsibility to medical associations, governments avoid further confrontation with a profession intent on retaining some autonomy over the fee-setting process, while the medical association faces the difficult task of balancing the interests of a membership increasingly fragmented along specialty lines. For these reasons, there is a reluctance to radically alter the fee structure: "Revisions to the internal weights of the schedule are politically difficult and dangerous for the profession, as they tend to undermine and fragment the united front. And provincial governments have neither the interest nor the expertise to take on the political risks of a struggle with physicians over the internal structure of the schedule." 38

Figure 6 displays the average fee-for-service payments received by physicians who billed at least $\$ 60,000$ during the fiscal year 2009/2010. Comparisons across provinces should be treated with caution since it includes only fee payments and, therefore, is not strictly comparable to the data presented in Figure $4 .{ }^{39}$ With this caveat in mind, it shows less variation in earnings across provinces, especially when compared on the basis of broad areas of specialization, slightly higher earnings in Ontario and the Prairie provinces, and lower earnings in Quebec. More salient is that, with the exception of P.E.I., the premium earned by medical and surgical specialists is fairly consistent across provinces. For the country as a whole, medical specialists earned roughly 20 per cent more and surgical specialists 50 per cent more, than family practitioners.

Katz et $\mathrm{al}^{40}$ suggest that the fee determination process has historically favoured those in family medicine for several reasons: their larger numbers, their greater cohesiveness by virtue of a similar work experience, and, given their more even geographical distribution, the system of voting along geographical lines gives them greater representation on bargaining committees than their overall percentage of the workforce would suggest. They go on to suggest that this translated into a redistribution of income in favour of GPs over the 1970s and 1980s, with the implicit goal of increasing the average income of GPs to 80 per cent of that for specialists. ${ }^{4 l}$

What data exists, however, does not support this story. Figure 8 outlines the annual average fee-for-service payments received by GP/FPs, medical specialists and surgical specialists expressed as a ratio of the average physician over the period 1972/73 to 2009/10. It indicates that since 1981 there was significant erosion in the position of FPs/GPs relative to medical specialists and surgical specialists. Part of the gap may be explained by the growth of alternative forms of remuneration (salary, capitation, block funding, blended, emergency room and on-call payments) in the past decade since they are more common among FPs/GPs and medical specialists, but this alone is not enough to account for the differences.

\footnotetext{
38 M. L. Barer, R.G. Evans and R. Labelle, The Frozen North: Controlling Physicians Costs through Controlling Fees - The Canadian Experience, 1-24.

39 Data in Figure 6 (based on the National Physician Database) differs from the National Health Expenditure data (presented in Figure 4) because: a) the numerator excludes alternative clinical payments, non-clinical payments and income from privately funded services; b) the denominator includes a more restrictive count of physicians; and c) it refers to the 2009-2010 fiscal year rather than the 2010 calendar year.

40 Steven J. Katz et al., "Physician Relations in Canada: Shooting Inward as the Circle Closes."

41 ibid., 1416-17.
} 
FIGURE 7: AVERAGE GROSS FEE-FOR-SERVICE INCOME, BY SPECIALTY AND PROVINCE, 2009-2010

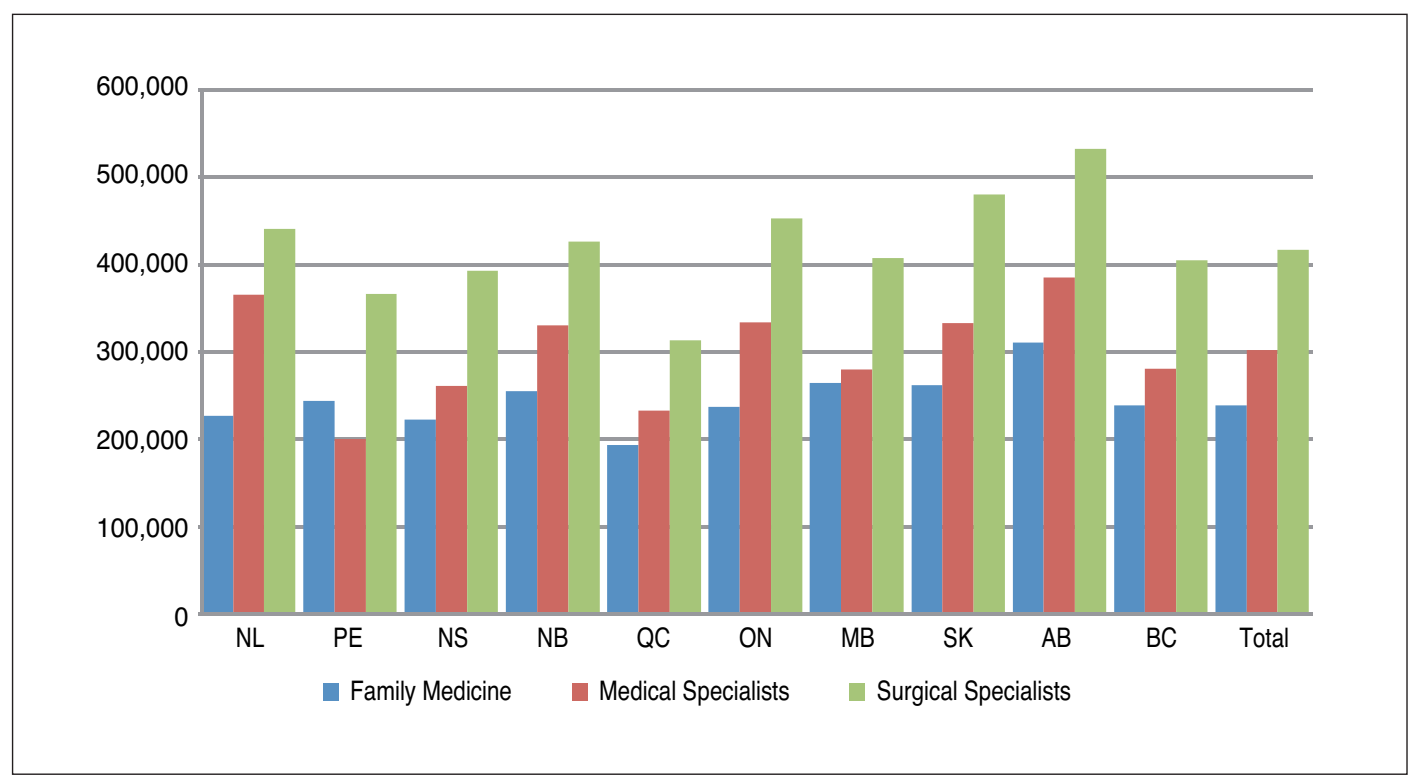

Source: CIHI, National Physician Database - Data Release, 2009-2010 (Ottawa, 2012).

FIGURE 8: FEE PAYMENTS/PHYSICIAN, BY SPECIALTY, 1972-2010 (INDEX, ALL PHYSICIANS = 100)

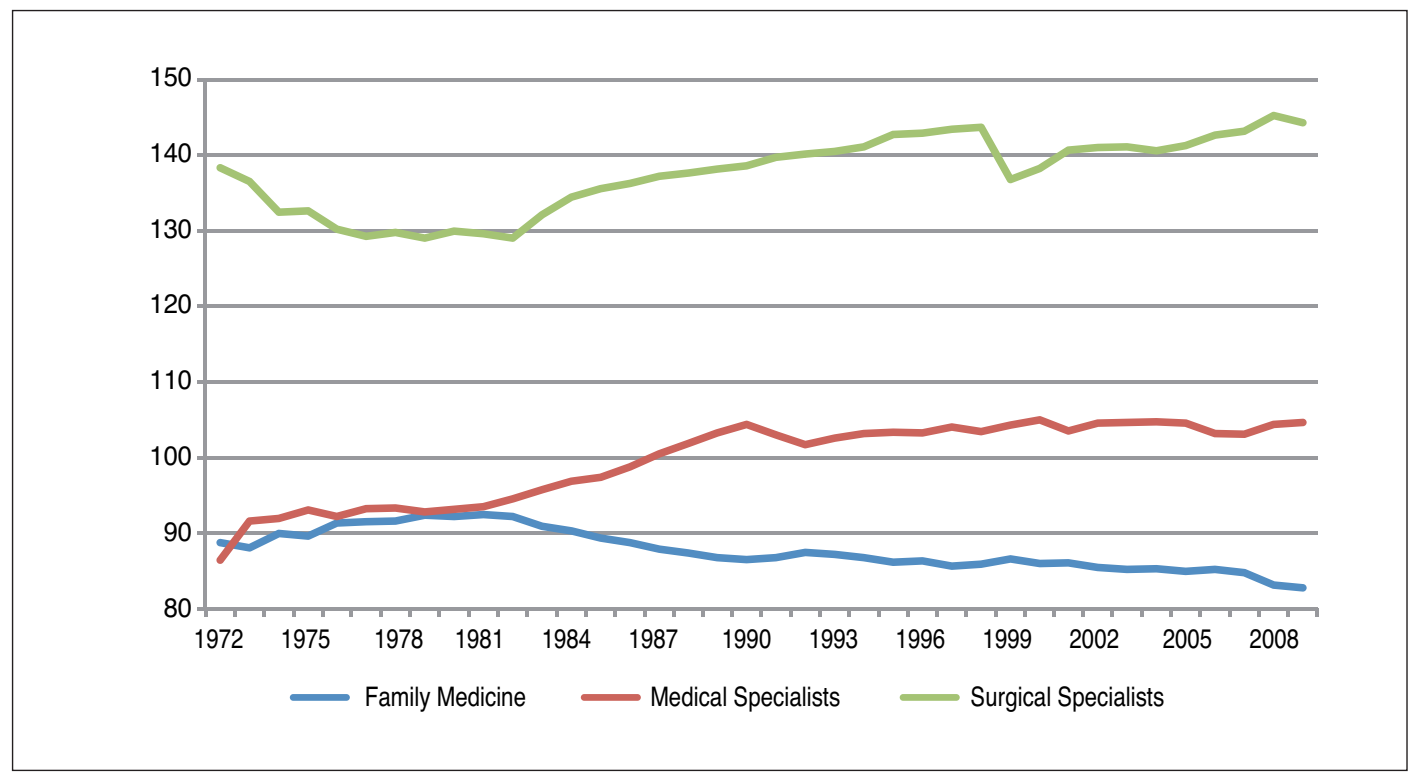

Notes: for fiscal year beginning in March. Data from 1972-1999/2000 are based on all physicians billing at least once per quarter; afterwards, all physicians billing at least $\$ 60,000$ per fiscal year. 


\section{DECOMPOSING TRENDS IN EXPENDITURES AND INCOMES}

To appreciate more fully the factors influencing changes in average earnings and expenditures of physician services, it is useful to follow the practice of others by isolating the price and quantity (utilization and capacity) components of total expenditures and incomes. ${ }^{42}$

\section{Fees, Utilization and Capacity}

From the perspective of the representative physician, annual gross income (INC/PHY) is equal to the product of expenditures on physician services per capita (EXP/POP) and population per physician (POP/PHY). Per-capita expenditures can be further divided between price and quantity components, or the average fee (FEE) and utilization per capita (UTIL/POP):

$$
\text { INC/PHY = FEE } \times \text { UTIL/POP } \times \text { POP/PHY }
$$

This identity can be rearranged to better reflect the perspective of the payer. In this case, the cost of physician services per capita can be expressed as the product of the average fee, utilization per physician and the physician/population ratio:

$$
\mathrm{EXP} / \mathrm{POP}=\mathrm{FEE} \times \mathrm{UTIL} / \mathrm{PHY} \times \mathrm{PHY} / \mathrm{POP}
$$

By taking the natural logarithms of the terms in equations (1) and (2), the annual rate of change in average income can be approximated as the sum of the annual rates of change in fees, utilization per capita and population per physician; and the annual rate of change in expenditures per capita is roughly equivalent to the annual rates of change in fees, utilization per physician and physician/population ratio:

$$
\begin{aligned}
& {[\mathrm{INC} / \mathrm{PHY}]^{*}=[\mathrm{FEE}]^{*}+[\mathrm{UTIL} / \mathrm{POP}]^{*}+[\mathrm{POP} / \mathrm{PHY}]^{*}} \\
& {[\mathrm{EXP} / \mathrm{POP}]^{*}=[\mathrm{FEE}]^{*}+[\mathrm{UTIL} / \mathrm{PHY}]^{*}+[\mathrm{PHY} / \mathrm{POP}]^{*}}
\end{aligned}
$$

where []$^{*}$ denotes the annual rate of change.

For the physician, therefore, income will rise with higher fees, more services provided per capita and a higher population-to-physician ratio. For the payer intent on limiting expenditures per capita, it will seek to restrict the growth in fees, utilization per physician and physicians per capita.

${ }^{42}$ R.G. Evans, "Beyond the Medical Marketplace: Expenditure, Utilization and Pricing of Insured Health Care in Canada" ; M. L. Barer and R.G Evans, "Prices, Proxies and Productivity: An Historical Analysis of Hospital and Medical Care in Canada," in Price Level Measurement: Proceedings from a Conference Sponsored by Statistics Canada, eds. W.E. Diewert and C. Montmarquette, Ottawa, 1983; M. L. Barer and R.G Evans "Riding North on a South-Bound Horse? Expenditures, Utilization and Incomes in the Canadian Health-care system"; and M. L. Barer, R.G. Evans and R. Labelle, The Frozen North: Controlling Physicians Costs through Controlling Fees — The Canadian Experience. 
Figure 9 displays the results of this exercise from the physician's perspective. Since the introduction of public health insurance, average real earnings rose by nearly 50 per cent. This increase occurred despite the average fee remaining virtually unchanged in real terms and despite a decline in the population-to-physician ratio of some 40 per cent. What drove the increase in earnings was a remarkable growth in utilization per capita in the order of 140 per cent.

Figure 10 rearranges the same data from the perspective of provincial health authorities. Spending of physician services per capita rose by 140 per cent. This increase was essentially split between two factors: an increase in utilization per physician and a greater number of physicians per capita.

FIGURE 9: TRENDS IN AVERAGE REAL EARNINGS, 1971-2010, INDEX OF FEES, UTILIZATION AND CAPACITY (1971 = 100)

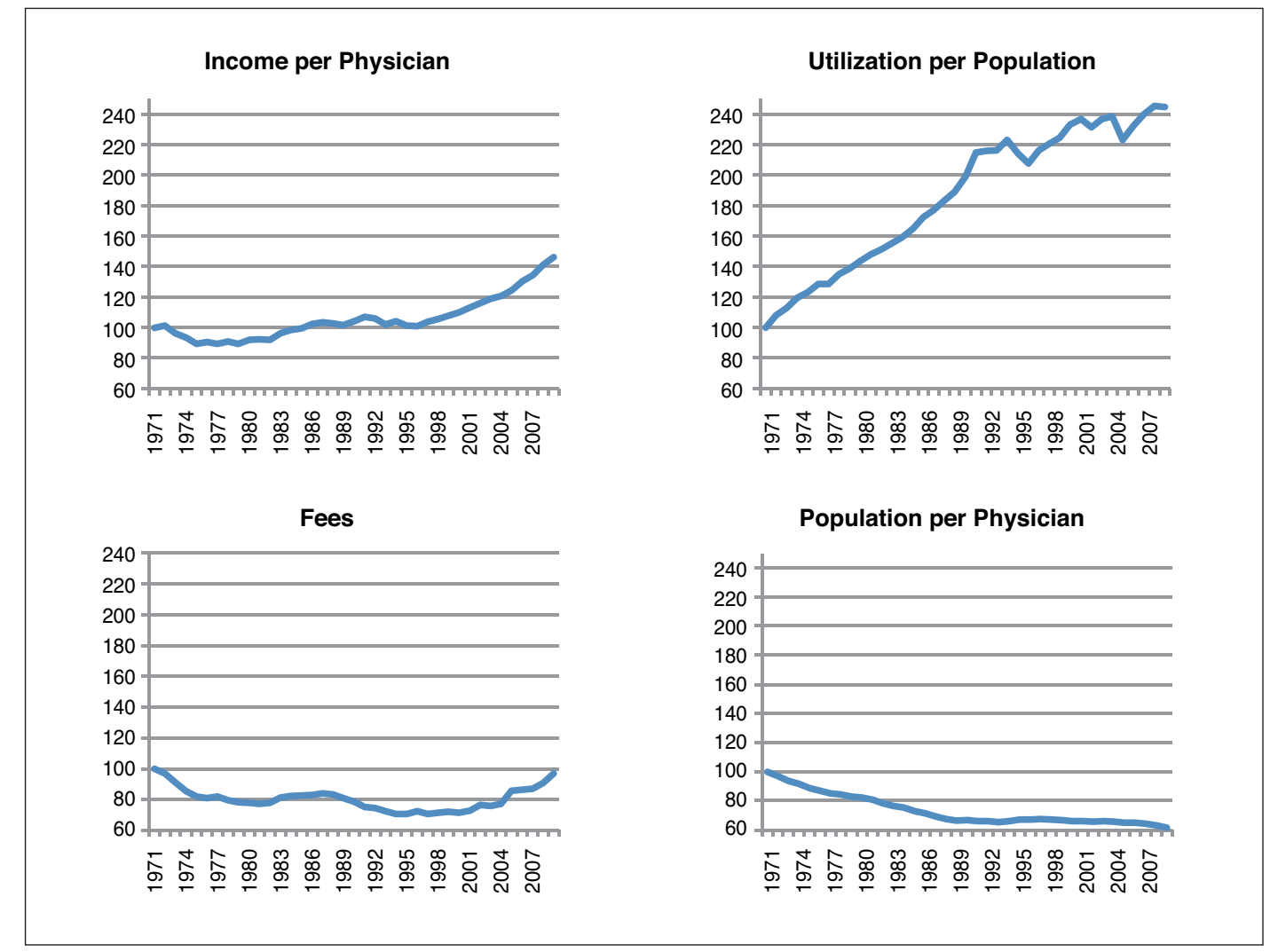


FIGURE 10: TRENDS IN REAL EXPENDITURES, 1971-2010, INDEX OF FEES, UTILIZATION AND CAPACITY (1971=100)

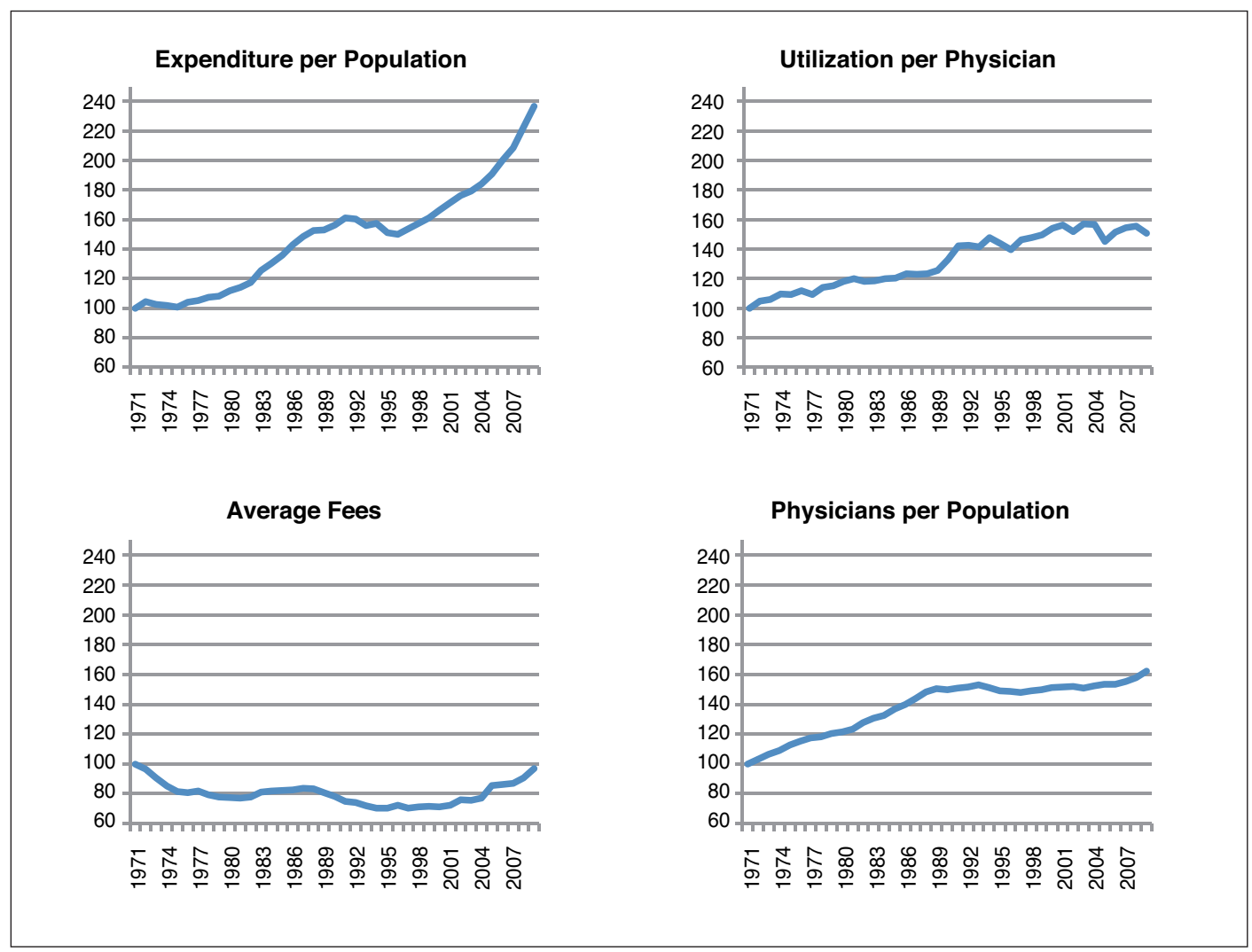

\section{Changes in the Pattern of Remuneration and Spending}

In order to consider the change in fees, utilization and capacity according to the periods outlined earlier, Figure 11 displays the changes from the perspective of the representative physician (income per capita) and Figure 12 from the provincial government's perspective (expenditures per capita). All changes referred to below are expressed in annual rates.

\section{1-1979}

The 1970s were marked by a sharp decline in the real value of fees. Despite a rapid increase in utilization per capita (four per cent), physicians suffered a significant loss in real income (-1.32 per cent). Expenditures per capita by provincial governments, however, rose by 1.0 per cent because there were more physicians per capita ( 2.36 per cent) and each physician was providing more services (1.78 per cent).

\section{9-1991}

Utilization and capacity continued to increase rapidly during the 1980s, while fees fell at a much more moderate pace (-0.30 per cent). For physicians this resulted in a healthy increase in earnings (1.34 per cent); for provincial governments it led to a rapid increase in expenditures per capita (3.1 per cent). 


\section{1-1996}

The introduction of global expenditure caps in the early 1990s achieved the reduction in utilization rates for which they were designed: for the first time since the introduction of public insurance, utilization fell ( -0.78 per capita and -0.42 per physician). By limiting total remuneration, global caps also provided an incentive for physician organizations to agree to limit the rate of growth in the number of physicians such that the physician-to-population ratio also fell for the first time since the introduction of public insurance (by -0.36 per cent). Combined with a -0.54-per-cent decline in fees, physicians suffered a significant loss in average earnings ( -0.96 per cent) and expenditures per capita fell more sharply ( -1.32 per cent).

\section{6-2001}

Immediately following the removal of global expenditure caps, there was a return to the general pattern established in the 1970s. Fees were virtually unchanged, but utilization rates again rose rapidly (2.7 per cent per capita and 2.3 per cent per physician) and the physician-topopulation ratio was again rising ( 0.4 per cent). The net effects were rapid increases in average earnings ( 2.3 per cent) and expenditures per capita ( 2.7 per cent).

\section{1-2009}

Since 2001 there has been a significant change in the pattern of remuneration and expenditures. Most notable is that after 30 years of tight control, fees have increased at a remarkable annual rate (3.7 per cent). Also unique has been the change in utilization rates. The modest increase in utilization per capita ( 0.40 per cent) has occurred despite the average physician providing fewer services ( -0.45 per cent), and because of the higher physician-population ratio ( 0.85 per cent). Primarily because of the increase in fees, the rise in the earnings of physicians (3.2 per cent) and expenditures per capita (4.1 per cent) have occurred at their fastest rate since the introduction of public insurance.

\section{FIGURE 11: AVERAGE EARNINGS OF PHYSICIANS, COMPONENTS - ANNUAL RATES OF CHANGE}

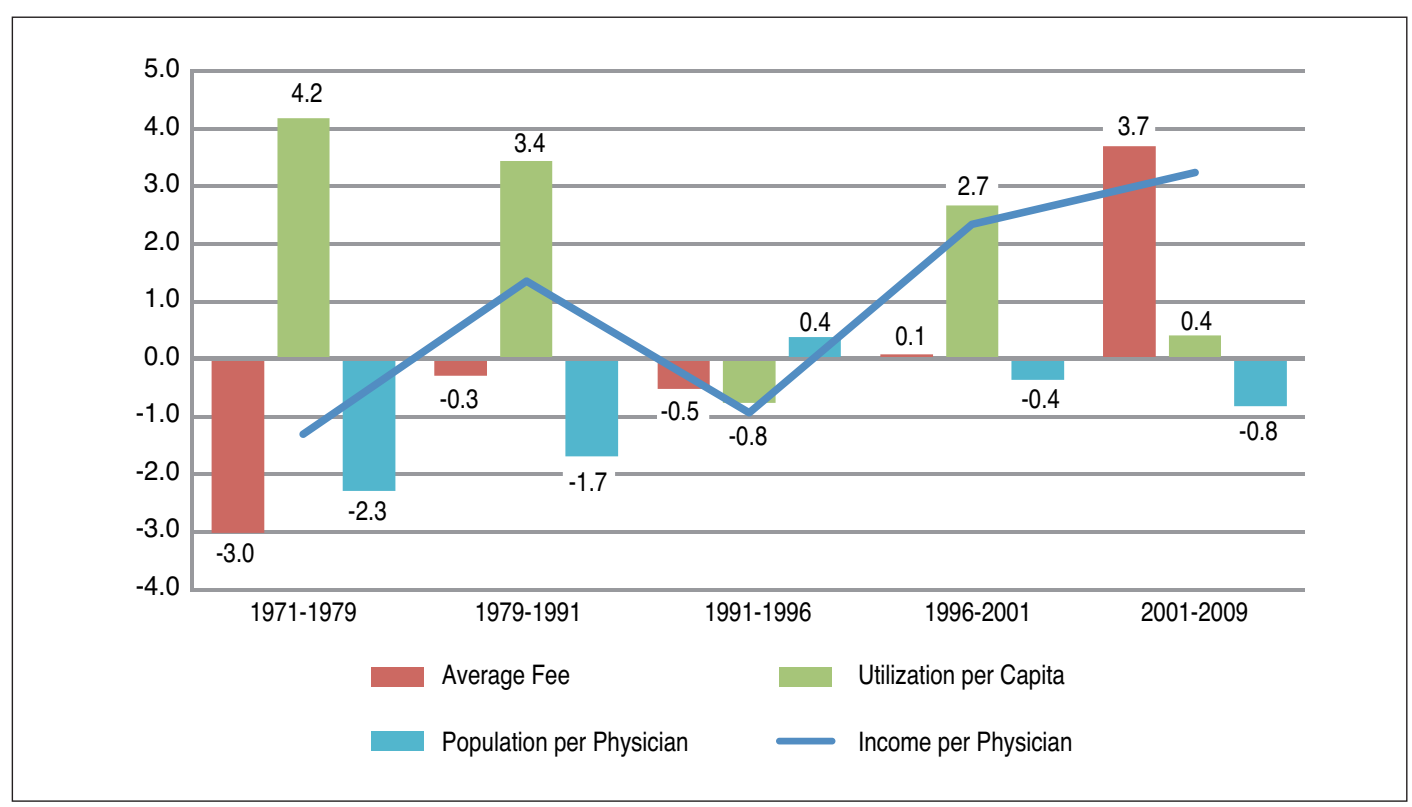


FIGURE 12: EXPENDITURES PER CAPITA, COMPONENTS - ANNUAL RATES OF CHANGE

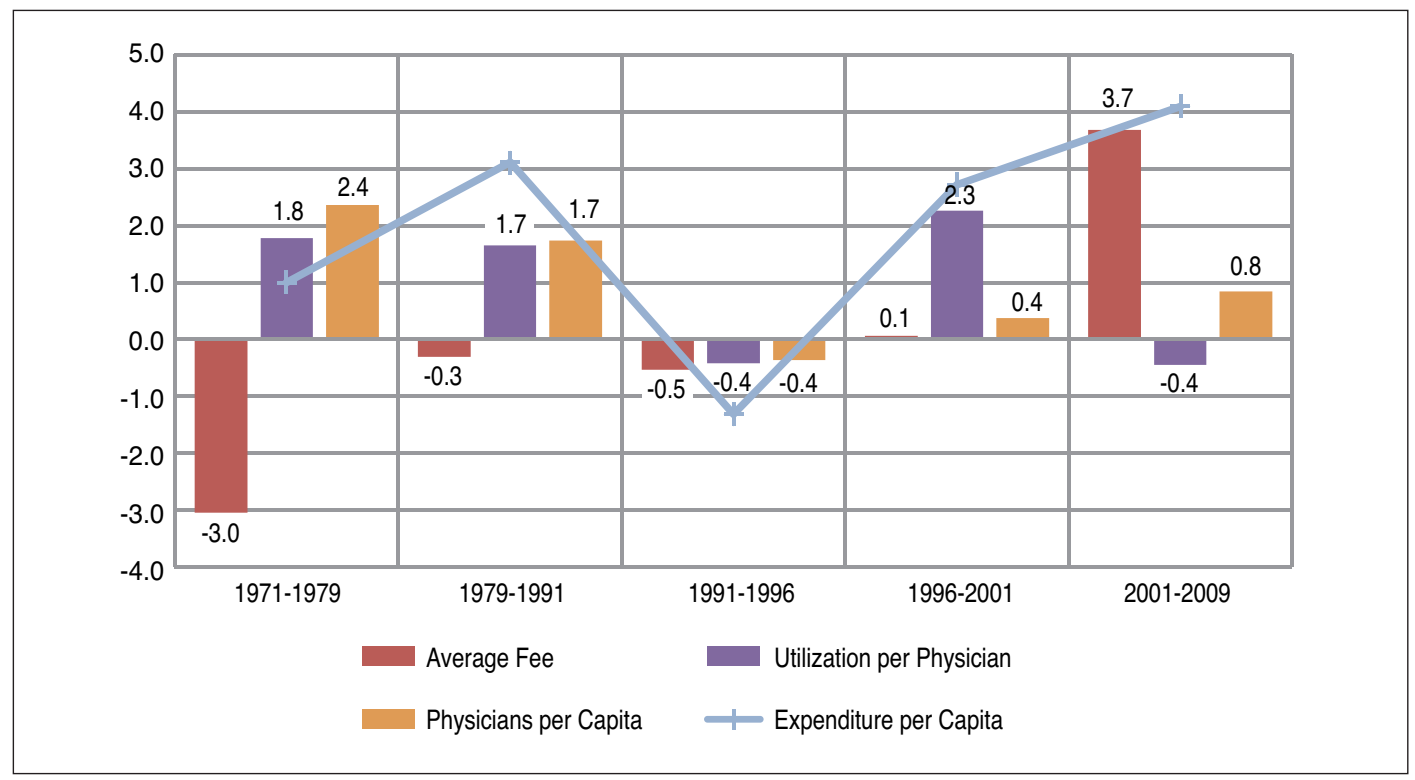

\section{Summary}

Canada's approach to the provision of physician services rests on the incomplete division between public funding and private delivery. Assigning to physicians the major role in the allocation of resources is designed to respect the physician's professional autonomy in making the best decision on behalf of the patient. Under the system of negotiations between the government and physician organizations, however, the public payer has experienced persistent problems in controlling the level of utilization, or services provided, and thus the overall level of spending on physician services. During periods of provincial fiscal constraint, this has led governments to take the exceptional measure of unilaterally imposing a settlement in the form of a global budget and/or limits on the earnings of individual physicians.

Since the introduction of public insurance for physician services, there has been a secular increase in the average earnings of physicians. This upward path was interrupted on two occasions: during the early 1970s (shortly after public health insurance was introduced throughout the provinces), and in the early 1990s (with the implementation of global expenditure caps). In 2010, the average Canadian physician earned a net income of $\$ 248,113$, roughly 4.5 times the earnings of the average Canadian worker. This increase has been central to maintaining relatively peaceful physician-government relations.

Examining differences across provinces must be treated with caution, but doing so suggests that earnings tend to be higher in Ontario and the Prairie provinces and persistently low in Quebec. There does, however, appear to be sufficient physician mobility between provinces for a degree of convergence over time. The gap in gross fee-for-service earnings between specialists and general and family practitioners has steadily increased since the early 1980s, however this may exaggerate the difference in total earnings given the increasing prevalence of alternative forms of remuneration. 
Decomposing the change in average incomes into its fee, utilization and capacity components highlights the uniqueness of the current nature of physician compensation. Between 1971 and 1991, provincial health authorities kept a tight check on fees, but were either unwilling or unable to control rapid increases in utilization, or the quantity of services provided. After 1975, this led to a steady increase in the real average earnings of physicians in the order of one per cent a year. When the growth in capacity (or the physician-to-population ratio) is added to the picture, per capita expenditures on physician services rose at an even faster rate, in the range of two per cent annually. When faced with fiscal problems in the early 1990s, all provinces adopted some form of global expenditure caps, which not only reduced fees but, for the first time, brought about a reduction in utilization and capacity. The result was a sharp decline in both physician incomes and government expenditures. These extraordinary measures, which breached the norms of collective bargaining with physician organizations, were a temporary expedient and, afterwards, physicians relied upon a range of more sophisticated forms of job action to recover the ground lost in the early 1990s.

What distinguishes the period since 2001 is not just the rapid increase in the average real income of physicians (at a rate in excess of three per cent annually), but how they have increased. For the first time, the average fees have outstripped inflation by a sizeable rate (3.7 per cent annually), while the growth in utilization and capacity has been moderate by historical standards. This reflects both the price that governments were willing to pay to buy peaceful relations as well as an apparent swing in public sentiment towards seeing physicians, rather than governments, as the guardians of access to health care.

\section{CONCLUSION}

\section{A New Era in Physician-Government Relations?}

In light of the large negotiated increases that followed the heightened conflict in the late 1990s, the Commission on the Future of Health Care in Canada - the "Romanow Commission" warned that the income of physicians threatened to become a significant cost driver and, accordingly, urged "provider associations and governments to consider the impact of future negotiations on the sustainability of medicare." ${ }^{43}$ Arguments that the Canadian health-care system is not fiscally sustainable are not new. However, the distinguishing characteristic of the current public debate is the extent to which the current bargaining model - based upon a negotiated settlement of the overall increase in fees, but leaving to physician organizations to decide how to distribute the increase across specific fee items - is an obstacle to meeting public health-care objectives.

The most immediate target for reform is the payment of physicians on a fee-for-service basis. ${ }^{44}$ As the Romanow Commission affirmed: "Paying physicians for each separate service they provide can create a perverse incentive to focus on the quantity of services provided rather than

\footnotetext{
${ }^{43}$ Commission on the Future of Health Care in Canada, Building on Values: The Future of Health Care in CanadaFinal Report (Romanow Report), Ottawa 2002, 102.

44 J.C. Herbert Emery, Chris Auld and Mingshan Lu, "Paying for Physician Services in Canada: The Institutional, Historical and Policy Contexts. Part 1 of Incentive Effects on Physician Remuneration Schemes," Institute for Health Economics, Working Paper 99-6, Edmonton 1999. For the United States, see: D. A. Barr, "Bending the Medicare Cost Curve for Physicians' Services: Lessons Learned from Canada," Journal of General Internal Medicine 17 (2012): 1555-9.
} 
on the quality of services in order to maximize a physician's income." Nonetheless, the commission was cognizant of the well-known shortcomings of alternative payment schemes: "Salaried doctors may choose to provide only the minimum service required knowing it will not affect their income, and capitation can provide an incentive for doctors to only accept healthy patients on a roster because they will require less time for care. Indeed, there is some evidence to suggest that mixed payment schemes may offer the best compromise for securing doctors' incomes and allowing them more time to care for individual patients." 45

But the Romanow Commission went further in identifying other shortcomings in the current method of physician remuneration. It argued that current fee schedules did not provide incentives for providing more comprehensive care focused on prevention and, more generally, that negotiations should extend to include the "deliverables physicians are expected to provide in exchange for increasing payments."

More far-reaching change is required to accommodate alternative methods of delivering primary health care. Both the Romanow Commission and the Kirby Report ${ }^{46}$ endorsed the adoption of interdisciplinary teamwork among health-care providers to ensure that services better address population needs and do so more efficiently. To the extent that this entails devolution of decision making to regional health authorities and community-based organizations, the Romanow Commission noted the difficulty in aligning incentives.

"Currently, regional health authorities in most provinces are responsible for the organization and delivery of health care services, including primary health care. Physicians directly affect much of the services regional health authorities are expected to provide from diagnostic tests to surgical time. Yet, fee-for-service physicians bill directly to the provincial government insurance plan for payment. Arguments have been made that this separation between the people in charge of 'organizing services' and the people in charge of 'paying doctors' further inhibits the development of primary health care and must be resolved."

Whatever changes emerge, there is a clear message for physician organizations. Under the public-funding/private-delivery model, physicians, as a self-regulating profession, retain much control over resource allocation. At the same time, however, it places them, as a group, in an agency role with government funders. If there is a perceived failure to provide adequate service commensurate with the overall level of remuneration, it may well be argued that they have breached their agency responsibilities. Both the "fee grabbing" that characterized physician behaviour in some provinces under the imposition of global budgets in the early 1990s, and the "bear pit" sessions that mete out fee increases across specialties, hardly inspire a sense of confidence in the profession's capacity to provide an equitable distribution of income, nor one that is necessarily in keeping with public health-care objectives. Unless physician organizations assume a broader self-governance role, they merely invite greater government involvement in resource allocation decisions.

\footnotetext{
45 Commission on the Future of Health Care in Canada, Building on Values: The Future of Health Care in CanadaFinal Report.

46 Senate Standing Committee on Social Affairs, Science and Technology, The Health of Canadians - The Federal Role, Final Report, (The Kirby Report), Ottawa 2002.

47 Commission on the Future of Health Care in Canada, Building on Values: The Future of Health Care in CanadaFinal Report, 124.
} 


\section{Ontario's Shot Across the Bow}

Recent newspaper accounts of the number of "millionaire doctors" in various provinces indicate a shift - or a campaign to shift - public sentiment by emphasizing the burden of health-care expenditures on taxpayers. ${ }^{48}$ Rising physician incomes during a period of fiscal constraint have proved an easy target in Ontario. The report of the Commission on the Reform of Ontario's Public Services ${ }^{49}$ - the "Drummond Report" - recommended in October 2012 that the province "aggressively negotiate with the Ontario Medical Association for the next agreement" and that "it is reasonable to set a goal of allowing no increase in total compensation. ${ }^{, 50}$ The negotiated settlement reached a month later and subsequently ratified by Ontario's doctors included just such a freeze on total remuneration, or the imposition of global expenditure caps for two years. ${ }^{5 l}$ But it also went further by adjusting specific fees and by establishing pay cuts for specific groups of specialists.

While the fiscal problems facing Ontario are more acute than in other provinces, it seems likely that similar efforts to constrain physician incomes will spread throughout the country. Three days after the agreement in Ontario was reached, the government of Alberta unilaterally imposed a four-year compensation package on its physicians. ${ }^{52}$ Despite providing funding to allow average incomes to rise with the cost of living, the extraordinary measure of breaking off negotiations with the Alberta Medical Association in order to impose a settlement bodes ill for the existing framework of physician-government relations.

The Drummond Report echoes many of the other sentiments expressed by the Romanow Commission, insisting that "negotiations must go well beyond compensation" in order to "address the integration of physicians into the rest of the health care system." Among the issues raised are a greater use of interdisciplinary health-care teams, rather than single-physician or small-group practices, to allow better use of other health-care practitioners in order to deliver services at a lower cost; greater use of salary/capitation modes of compensation rather than feefor-service payments which are characterized as giving "an incentive for medical interventions without due consideration to quality and efficiency of care"; more direct government involvement in the adjustment of the fee schedule; and "focusing the Ontario Medical Association's negotiations more on quality of care and amending payment systems for physicians and throughout the health care system.."53

48 Karen Howlett, "Six Ontario doctors each billed taxpayers more than \$3-million last year," Globe and Mail, September 26, 2012; Bruce Owen, “16 Million-Dollar MDs in Manitoba," Winnipeg Free Press, October 13, 2012.

49

Commission on the Reform of Ontario's Public Services. Public Services for Ontarians: A Path to Sustainability and Excellence (the Drummond Report), Province of Ontario, 2012..

50 ibid., 189.

${ }^{51}$ Karen Howlett, "Ontario in landmark deal to freeze pay for physicians," Globe and Mail, November 13, 2012; Karen Howlett "Ontario doctors back deal freezing pay for two years," Globe and Mail, December 9, 2012.

52 Jamie Komarnicki, “Alberta health minister imposes \$463-million, four-year deal on doctors," Calgary Herald, November 16, 2012; Dawn Walton, "Alberta Teachers, Doctors Press PCs on Unresolved Labour Issues," Globe and Mail, November 30, 2012.

53 Commission on the Reform of Ontario's Public Services. Public Services for Ontarians: A Path to Sustainability and Excellence, 188-92. 
Recommendations of this nature call for government planning and/or negotiations over matters that may be perceived as encroaching upon decision making that has been in the traditional domain of physicians. No one disputes that reform of the health-care system is required; however, it remains to be seen if the appropriate reform can be achieved through the traditional mechanism of collective bargaining.

TABLE 1: TRENDS IN AVERAGE EARNINGS PER PHYSICIAN, BY COMPONENT

\begin{tabular}{|l|c|c|c|c|}
\hline \multirow{2}{*}{ Period } & \multicolumn{4}{|c|}{ Annual Rate of Change } \\
\cline { 2 - 5 } & $\begin{array}{c}\text { Income per } \\
\text { Physician }\end{array}$ & Average Fee & $\begin{array}{c}\text { Utilization } \\
\text { per Capita }\end{array}$ & $\begin{array}{c}\text { Population } \\
\text { per Physician }\end{array}$ \\
\hline $1971-1979$ & -1.32 & -3.05 & 4.18 & -2.30 \\
$1979-1991$ & 1.34 & -0.30 & 3.43 & -1.72 \\
$1991-1996$ & -0.96 & -0.54 & -0.78 & 0.36 \\
$1996-2001$ & 2.33 & 0.06 & 2.65 & -0.38 \\
$2002-2010$ & 3.23 & 3.69 & 0.40 & -0.84 \\
\hline
\end{tabular}

TABLE 2: TRENDS IN EXPENDITURES ON PHYSICIAN SERVICES, BY COMPONENT

\begin{tabular}{|l|c|c|c|c|}
\hline \multirow{2}{*}{ Period } & \multicolumn{4}{|c|}{ Annual Rate of Change } \\
\cline { 2 - 5 } & $\begin{array}{c}\text { Expenditure } \\
\text { per Capita }\end{array}$ & Average Fee & $\begin{array}{c}\text { Utilization } \\
\text { per Physician }\end{array}$ & $\begin{array}{c}\text { Physicians } \\
\text { per Capita }\end{array}$ \\
\hline $1971-1979$ & 1.00 & -3.05 & 1.78 & 2.36 \\
$1979-1991$ & 3.11 & -0.30 & 1.65 & 1.75 \\
$1991-1996$ & -1.32 & -0.54 & -0.42 & -0.36 \\
$1996-2002$ & 2.72 & 0.06 & 2.27 & 0.38 \\
$2002-2010$ & 4.10 & 3.69 & -0.45 & 0.85 \\
\hline
\end{tabular}




\section{APPENDIX: DATA SOURCES AND DEFINITIONS}

It is tempting to complain about too much, rather than too little, data when trying to ascertain the earnings of Canadian physicians. The concern is over the quality and compatibility of the data drawn from five sources: 1) The Canada Revenue Agency's Taxation Statistics (TAX); 2) health-care expenditures on physician services included in the National Health Expenditure Database (NHEX); 3) average-payments-per-physician data from Health Canada's/CIHI's Medical Services Database and National Physician Database (APP); 4) reports derived from the CIHI's National Physician Database beginning in 1999/2000 (NPDB); and 5) self-reported income from the census of Canada (CENSUS).

\section{Canada Revenue Agency Taxation Statistics, 1945-1995}

In 1946, the Canada Revenue Agency (the Department of National Revenue as it was called at the time) began publishing data from an annual sample of individuals' income tax returns. The occupational category of "Self-Employed Medical Doctors and Surgeons" covered physicians who derived more than half of their income from a fee-for-service professional practice. Various measures of income - including net professional earnings and total income from all sources - are provided for all tax returns as well as the subset of taxable returns. The latter is a better basis for comparison with other occupations because of the number of non-taxable returns files by individuals not in the labour force.

Until 1984, occupational data was also published at the provincial level; between 1985 and 1992, unpublished information remained available upon request; and after 1995, data by occupation and province was no longer tabulated.

Income estimates were initially based upon a 10-per-cent stratified sample of tax returns from each district office. Beginning with the 1956 data, a 5-10-100-per-cent sliding scale was adopted. For larger districts, all returns reporting a total income in excess of $\$ 20,000$, and five per cent of those reporting $\$ 20,000$ or below, were included in the sample; for smaller districts, all returns reporting total income in excess of $\$ 15,000$, and 10 per cent of those reporting $\$ 15,000$ or below, were included in the sample. This was designed to increase the accuracy of published figures despite reducing the sample to between six and seven per cent of all returns. For physicians, the number of returns sampled would have increased dramatically because of the incidence of those reporting total income in excess of $\$ 15,000$ or $\$ 20,000$. (In 1958, for instance, 24 per cent of tax returns filed by "Self-Employed Medical Doctors and Surgeons" reported total income over $\$ 20,000$, and 18 per cent reported total income between $\$ 15,000$ and $\$ 19,999$.)

Some caveats apply: individuals may misreport their occupation; their reported income may be for a fiscal year that does not coincide with the calendar year; the province in which the individual files the tax return may not be the province in which the majority of income was earned; and the income of non-residents is included in the "Canada" figures. 
Health Canada (then: Health and Welfare Canada or HWC) had three concerns with the information provided by the Canada Revenue Agency (CRA): 1) a potential sampling error; 2) changes in how net income was reported for tax purposes after 1973; and 3) the degree of coverage in some provinces, particularly Alberta, where physicians were permitted to incorporate. Accordingly, in a series of occasional publications, it produced its own estimates of physician income (gross and net of expenses) from published and unpublished CRA data and grew increasingly wary of the results.

The potential sampling error arose from a combination of two factors: there were different degrees of coverage depending upon income thresholds; and the sample was not stratified by occupation. As a result, physicians earning above a certain threshold were over-sampled, while those under the threshold were under-sampled. This made the published data less reliable, particularly when reported at the provincial level where the numbers earning below the threshold were quite small. To address this concern, Health Canada counted the number of selfemployed, active physicians from provincial registries and then blended some regional data (the "consolidation technique") to derive provincial-level estimates. To take advantage of the over-sampling of physicians in higher income brackets, it also produced income estimates for full-time fee-practice physicians, defined as those with annual incomes above a given threshold. For the years 1973 and 1979 through 1982, Health Canada went even further and used the raw data to produce income estimates based on the universe of self-employed physicians filing tax returns.

The second problem, that of how income was being reported, was in part due to "clinical distortions" where the incomes of physicians working on a salaried basis in a large clinic or group practice were included in the aggregate gross income and expenses of the clinic owner. Since salaried physicians were excluded in the count of fee-practice physicians, the mean gross income and expenses would be systematically overstated. Health Canada, therefore, made some imputations to estimate gross income and expenses, but reiterated that the "net professional income" figure was the most reliable. The chief contribution of Health Canada's reworking of the taxation data is estimates of practice expenses. Over the period 1957-1983, it provided mean gross and net income by province and by specialty (an analysis complemented by a special survey conducted for the year 1985) that gives useful historical benchmarks.

The third concern was that of declining coverage because of the trend towards incorporation. Throughout the 1946-1995 period, the annual number of taxable returns by physicians was roughly 80 per cent of active physicians (other than interns and residents) reported by Health Canada, and tended to decrease over time. Coverage in Alberta was low throughout (generally less than 45 per cent) and declined in B.C. over the period, reflecting the ease of incorporation in these provinces. To the extent that incorporated physicians tend to have higher incomes, the TAX data understates the annual earnings of all fee-for-service physicians. Despite this concern, no adjustment was made to the data by Health Canada.

The upshot is that the reworking of the data by Health Canada makes little difference in the estimated income of physicians at the national level. While addressing some questions about sampling errors in the TAX data, the nagging concern was the potential under-reporting of income, especially after 1973 when the income estimates began to diverge markedly from income estimates based on health expenditure data. Accordingly, Health Canada ceased distributing income estimates after the 1982 year "largely because of problems with some of the data," although information was made available until 1987. 
While the TAX data has some shortcomings - they only refer to fee-for-service physicians, the provincial-level data are less reliable particularly before 1956, and there may be an upward downward bias in reported income after 1973 - they provide a unique historical picture of trends in physician income over the 1946-1972 period. Afterwards, other data sources may provide more reliable estimates.

\section{National Health Expenditures on Physician Services, 1968 - present}

An alternative means of estimating the mean gross income of physicians is simply to divide total health-care expenditures on physician services by the number of physicians.

The numerator includes direct public and private spending on physician services as reported in the CIHI's National Health Expenditure Database (NHEX) and its predecessors. (Health Canada compiled data on health-care expenditures, by components, which were published in a series of occasional reports. The historical data was subject to continual revision.) This includes professional fees as well as alternative forms of payment (capitation, salaries and sessional), but excludes payments to salaried employees of hospitals and public-health agencies (this remuneration would be included under the hospital or other institutions category). Private spending on physician services is estimated from Statistics Canada survey data on household expenditures and accounts for less than two per cent of the total. It was highest during the period in which extra-billing was permitted (1976-1986), then fell to as low as 0.9 per cent, only to increase to 1.2 per cent by 2010 . Note, however, that in 2012 private spending on physician services was estimated to be only $\$ 13$ per capita. $^{54}$

Determining what, or whom, should be included in the denominator is more difficult. Drawing upon the annual CIHI publication Supply, Distribution and Migration of Canadian Physicians, we have used active civilian physicians, excluding interns and residents (since the bulk of their remuneration would also fall under the category of hospital expenditures). Because the numerator excludes the pay of salaried physicians working for hospitals and public agencies, while the denominator includes such salaried staff in the count of active physicians, estimates of average gross income are understated.

This data source has several virtues. First, coverage is more complete. It is not restricted to feefor-service physicians: it includes some, but not all, physicians receiving alternative forms of payment. Second, it is comprehensive in terms of considering all forms of remuneration (including, in theory, private expenditures on non-insured items). Third, the quality of the data, particularly after 1982, is high, given that it is based upon actual expenditures by provincial medical-care insurance plans. It should be noted that prior to 1983, expenditures of physician services was derived from the Canada Revenue Agency's taxation statistics and, as such, do not offer an alternative basis for estimation.

Information is available at the provincial level but not by specialty.

$\overline{54}$ Canadian Institute of Health Information, National Health Expenditure Trends, 1975-2012, 2012, Table A3.2.3. 


\section{Health Canada's/CIHI's Average Payments per Physician (APP), 1972/73-2004/05}

In 1990, Health Canada published retrospective data, back to the 1972/73 fiscal year, on the average fee payment per physician drawn from its Medical Care Database and later the National Physician Database (NPDB). With the creation of CIHI in 1993, this information was published annually under the title Average Payment per Physician Report, Canada and covered the period 1989/90-2004/05. Payments by specialty extend back to $1972 / 73$ and by province to $1989 / 90$.

The APP publications referred only to fee-for-service physicians and only to fee-for-service payments. In an effort to control for changes in the intensity of work among physicians across provinces, across specialties and over time, the APP report published several different counts of physicians. At various times it has provided information for: a) physicians receiving at least one payment during the fiscal year (ALL); b) physicians receiving at least one payment in each quarter (QUARTER); c) physicians earning over a particular annual threshold $(\$ 40,000$, $\$ 50,000$ or $\$ 60,000)$; and d) full-time equivalent physicians (FTE). Average payments per physician vary significantly depending on the coverage of physicians and, as expected, rise from category (a) through (d).

None provides an ideal basis for a time series. The first two categories (ALL and QUARTER) are defined consistently over time but make little or no accommodation for work intensity; the threshold measures are subject to the shortcoming that they capture a larger percentage of the physician population as inflation results in higher nominal incomes; and the definition of FTE has changed over time and with the selection of base year. Only the payments per physicians billing at least once per quarter (QUARTER) are published over the majority of the time period.

CIHI's complementary National Grouping System Categories (NGS) Report also draws from NPDB data. Of particular value are the estimates of average cost per service, a good proxy for the average fee.

\section{National Physician Database, 1999/2000 - present}

CIHI's National Physician Database (NPDB) incorporates the earlier Medical Care Database of Health Canada and APP and NGS reports continued to be issued annually. As before, these reports contain the amount that each physician billed (and received payments from) the provincial medical insurance plan for a particular fee-code item. This permits a precise measure of gross receipts per physician, including a breakdown by province and area of specialization. There is, however, a clear discontinuity in the data reported before and after 1999/2000.

The coverage and comprehensiveness (by sources of income) of NPDB reports diminished as a growing percentage of physicians received alternative forms of remuneration. For example, provincial comparisons of average incomes, based on fee-for-service payments, were vulnerable if the ratio of fee-payment to alternative forms of pay varied across provinces. Consolidation of the APP and NGS reports into the single National Physician Database Report - Data Release comes with the added benefit of data on alternative forms of remuneration as well as non-clinical payments. 


\section{Census of Canada}

The census of Canada provides estimates of the self-reported employment earnings of Canadians every five (previously 10) years. This is obtained from a sample of 20 per cent of the population that completes the long-form version, which contains several questions about labour-market activity and earnings.

Despite the obvious shortcoming that data are collected only once every five or 10 years (and that there is a considerable delay in reporting the results), the census figures provided useful benchmarks by virtue of the richness of the data. They include a breakdown of income by gender, full-time/part-time status and hours of work, two broad occupational categories ("General Practitioners and Family Physicians" versus "Specialist Physicians"), and geographical location (province and Census Metropolitan Area with a population over $100,000)$.

When interpreting census information of average income, it is important to note that it is based on the 1991 Standard Occupational Classification (SOC) in which interns and residents are included in both the "General Practitioners and Family Physicians" and "Specialist Physicians" categories.

\section{Data Compatibility}

Appendix Figure 1 displays the income estimates according to various sources. This includes:

a) TAX: the CRA's estimates of net professional income of self-employed physicians with taxable income;

b) APP-Q: the average gross income (fee payments only) per physician provided by Health Canada/CIHI for physicians who received at least one payment per quarter;

c) NHEX: estimated gross average income generated by dividing national health expenditures on physicians by the count of active civilian physicians (excluding interns and residents);

d) NPDB-Q: average gross income (fee payments only) per fee-for-service physicians receiving at least one payment in each quarter of the fiscal year beginning in April;

e) NPDB-FTE: average gross income (fee payments only) per full-time equivalent fee-forservice physician, for the fiscal year beginning in April;

f) CENSUS: average self-reported net income of all physicians (including interns and residents).

These series obviously measure different things, as they vary according to the type of income measures (net versus gross; fee payments versus all sources), the count of physicians (all, active civilian physicians excluding interns and residents, and fee-for-service only), and the time interval (calendar versus fiscal year).

The data displayed in Appendix Figure 1 makes one adjustment: each series is expressed in terms of net, rather than gross, income. This is done by applying the "rule of 35 per cent" to the NHEX, NPDB-Q and NPDB-FTE series; that is, we assume that expenses equalled 35 per cent of gross income and that this percentage has not changed over time. This is not an 
unrealistic assumption. According to Health Canada figures, between 1957 and 1982 expenses as a percentage of gross income varied between 31 and 38 per cent. The Canadian Medical Association's "Physician Resource Questionnaire" for 1997 found that overhead expenses (including all staff salaries and benefits) as a percentage of gross income were 37 per cent for GPs, 36 per cent for surgical specialists and 27 per cent for medical specialists. ${ }^{55}$ Similar results were reported for the 2002 survey: 35 per cent for GPs, 33 per cent for surgical specialists and 27 per cent for medical specialists. ${ }^{56}$

The ranking of the series "makes sense" given the differences in coverage (or how the denominator is defined in each case). Compared to NHEX estimates, which capture all forms of payments received by all physicians other than interns/residents, the TAX series provides relatively high estimates since it is dominated by full-time fee-for-service physicians; the APP$\mathrm{Q}$ and NPDB-Q figures are relatively low since they are limited to fee payments received by all active physicians. That the NPDB-Q figures provide a particularly low estimate is not surprising: it includes all physicians billing at least once per quarter in the fiscal year (thus capturing many part-time physicians), but only considers their fee-payment income. And the CENSUS figures are the lowest since they include the earnings of interns and residents.

The series are also largely consistent in terms of trends over time. Each indicates a marked decline in physicians' income throughout the 1970s, recovery during the 1980s, another sharp decline in the early 1990s, followed by higher incomes after 1995. The obvious exception to the overall pattern is the much sharper spike in the TAX/HWC series in the early 1970s.

\section{Composite Time Series}

For the purpose of historical comparisons, we rely on a composite time series, constructed by linking TAX and NHEX data series. For the period from 1968 onward, we take the estimated annual gross income derived from dividing total physician expenditures by the number of active civilian physicians (excluding interns and residents) and reduce this by 35 per cent in order to obtain estimated annual net income. For the period prior to 1968, we rely upon TAX data for the net professional income of self-employed physicians. Since the NHEX figure was 22 per cent higher than the TAX figure for 1968, the two time series are linked by reducing the TAX figures by 22 per cent throughout the period 1946-1968. This 22-per-cent figure is of a reasonable order of magnitude in that the reported earnings of self-employed physicians were 25 to 33 per cent higher than other physicians in the 1961 and 1971 census returns. Stated differently, we extend the NHEX estimates backward in time by applying the annual rates of change from the TAX series.

Our measure of relative income is similarly constructed. For the 1968 period, it uses the ratio of the NHEX average net income of physicians to the estimated annual income of all Canadian full-time, full-year workers. ${ }^{57}$ For previous years, we take the ratio reported in the TAX data (between self-employed physicians and all tax filers) and reduce this number by 22 per cent.

\footnotetext{
55 CMA, 1997.

56 CMA, 2002.

57 M. Urquhart and K.H. Buckley, Historical Statistics of Canada (Toronto: Macmillan, 1965), Series E49 and CANSIM Table 2020102.
} 


\section{Data Sources:}

\section{Canada Revenue Agency (Revenue Canada):}

Taxation Statistics (annual, 1946-1992). Ottawa, 1946-1994. (Unpublished data for 1993-1995 available upon request.)

\section{Health Canada (Health and Welfare Canada):}

1946-1955. Survey of Physicians in Canada (various years: July 1946, September 1949, June 1951, June 1954).

1958. A Survey of Medical Groups in Canada, 1954. Health Care series memorandum no. 7.

1963. Average Earnings of Physicians and Surgeons in Canada, 1957-1960.

Memorandum No. 18. October.

. 1966-1973. Earnings of Physicians in Canada (various years: 1957-1965; 19661967, 1967, 1959-1969, 1960-1970, 1961-1971, 1962-1972).

1985. Earnings of Physicians in Canada. April.

1988. Average Fee-Payment per Physician and Physician-Population Ratios. Ten Province Statistics. 1981-82 to 1986-87.

1988. Physicians' Income by Specialty Study, 1985.

1990. Statistical Summary. Number of Physicians and Fee-Payments per Physician, by Specialty. Ten Province Totals. 1972/72 - 1987/88.

1990. Medical Care Insurance Physician Fee-Practice - Services Provided - 198384 to 1987-88. Canada by Region.

1991. Average Fee-Payment for Full-Time Physicians by Specialty, Canada by Province, 1985-86 - 1988-89.

\section{National Health Expenditures:}

Canadian Institute for Health Information (CIHI). 2012. National Health Expenditure Trends, 1975-2012.

2000. Health Personnel in Canada, 1988 to 1997. Ottawa.

2004. National Health Expenditure Trends, 1975-2004.

2004a. Health Personnel Trends in Canada, 1993-2002. Ottawa.

1995. Health Personnel Trends in Canada, 1982-1992. Ottawa.

1986-1992. Health Personnel Trends in Canada (annual). Ottawa.

.1997-2012. Supply, Distribution and Migration of Canadian Physicians, 1970-

1995; 1999 .. 2011.

Health and Welfare Canada. 1969-1985. Canada Health Manpower Survey (annual). Ottawa.

1979. National Health Expenditures in Canada, 1960-1975. Ottawa.

1986. National Health Expenditures in Canada, 1970-1982. Ottawa. 


\section{National Physician Database:}

CIHI. 1998-2006. Average Payment per Physician Report, Canada, 1989-90 to 1993-94; 199394 to 1995-96; 1996-97 to 1998-99, 1999-2000 and 2000-2001; 2001-2002; 2002-2003; 20032004; and 2004-2005.

2001-2007. National Group System Categories (NGS) Report, Canada (annual) 1998-1999 . . 2004-2005.

2008-2012. National Physician Database - Data Release, 2006-2007 . . 2009-2010.

\section{Census of Canada:}

Rashid, Abdul. 1999. "Earnings of Physicians," Perspectives (Winter): 27-38 (Statistics Canada, cat. 75-001 xpe 27-38)

Statistics Canada. 1961. Census of Canada 1961. Bulletin 3.3: Labour Force Earnings, Hours and Weeks of Employment of Wage Earners by Occupation, Provinces, Vol. III, pt.3, Table 21. $.197 \mathrm{x}$

1981 Census of Canada, 92-930, Table 1

1993. Employment Income by Occupation, 93-332. Ottawa.

. 2004. Canada's Workforce: Paid Work, 2001 Census (cat. no.

97F0012XIE2001048).

\section{Fees:}

CIHI. 1998-2004. Physician Services Benefit Report, 1996/97-2002/03. Ottawa.

Health and Welfare Canada. 1986. Payment Schedule Increases: Canada by Province and Territories.

Health and Welfare Canada. 1991. Payment Insurance Increases: Medical Care Insurance Plans, 1990 Update.

Hicks, Vern, Gilles Fortin and Geoff Ballinger. 2001. Price Indexes Used in National Health Expenditures: Feasibility Study. Ottawa: CIHI. 
APPENDIX TABLE 1: COMPARISON OF DIFFERENT DATA SOURCES

\begin{tabular}{|c|c|c|c|c|c|}
\hline Source & Coverage & Frequency & Details & Income Measure & Data Quality \\
\hline $\begin{array}{l}\text { Taxation } \\
\text { Statistics } \\
\text { (TAX) }\end{array}$ & $\begin{array}{l}\text { Fee-For-Service } \\
\text { (excludes } \\
\text { incorporated) }\end{array}$ & annual, 1945-1995 & Provincial & $\begin{array}{l}\text { Net Professional } \\
\text { Income } \\
\text { Total Income } \\
\text { Taxable Income }\end{array}$ & 5-10\% sample \\
\hline $\begin{array}{l}\text { Health } \\
\text { Canada/Health } \\
\text { and Welfare } \\
\text { Canada } \\
\text { (HWC) }\end{array}$ & $\begin{array}{l}\text { Fee-For-Service } \\
\text { (excludes } \\
\text { incorporated) }\end{array}$ & annual, 1957-1987 & $\begin{array}{l}\text { Provincial } \\
\text { Specialty }\end{array}$ & $\begin{array}{l}\text { Gross Income } \\
\text { Net Income } \\
\text { Practice Expenses }\end{array}$ & $\begin{array}{l}\text { 5-10\% sample with } \\
\text { "consolidation } \\
\text { technique" applied }\end{array}$ \\
\hline $\begin{array}{l}\text { Health Care } \\
\text { Expenditure } \\
\text { Database } \\
\text { (NHEX) }\end{array}$ & $\begin{array}{l}\text { All physicians, } \\
\text { excluding } \\
\text { interns/residents }\end{array}$ & annual, 1960-present & Provincial & Gross Income & $100 \%$ \\
\hline $\begin{array}{l}\text { Average } \\
\text { Payment per } \\
\text { Physician } \\
\text { (MCDB/NPDB) }\end{array}$ & Fee-For-Service & $\begin{array}{l}\text { annual, fiscal year, } \\
\text { 1972/73-2004/05 }\end{array}$ & $\begin{array}{l}\text { Provincial } \\
\text { Specialty } \\
\text { Various income } \\
\text { thresholds }\end{array}$ & $\begin{array}{l}\text { Gross Income (fee } \\
\text { payments only) }\end{array}$ & $100 \%$ \\
\hline $\begin{array}{l}\text { Average } \\
\text { Payment per } \\
\text { Physician } \\
\text { (NPDB) }\end{array}$ & Fee-For-Service & $\begin{array}{l}\text { annual, fiscal year, } \\
\text { 1989/90- }\end{array}$ & $\begin{array}{l}\text { Provincial } \\
\text { Specialty } \\
\text { Various income } \\
\text { thresholds }\end{array}$ & $\begin{array}{l}\text { Gross Professional } \\
\text { Income (fee payments } \\
\text { only) }\end{array}$ & $100 \%$ \\
\hline $\begin{array}{l}\text { Census of } \\
\text { Canada } \\
\text { (CENSUS) }\end{array}$ & $\begin{array}{l}\text { All physicians, } \\
\text { including interns/ } \\
\text { residents }\end{array}$ & $\begin{array}{l}\text { every } 10 \text { years, } \\
1931-81 \text {; then every } \\
\text { five years }\end{array}$ & $\begin{array}{l}\text { Provincial } \\
\text { Gender } \\
\text { Work Intensity } \\
\text { GPs/Specialists }\end{array}$ & $\begin{array}{l}\text { Employment Income } \\
\text { Total Income }\end{array}$ & $20 \%$ sample \\
\hline
\end{tabular}

\section{APPENDIX FIGURE 1: $\quad$ AVERAGE NET INCOME, VARIOUS SOURCES, 1950-2010 (2010 CONSTANT DOLLARS)}

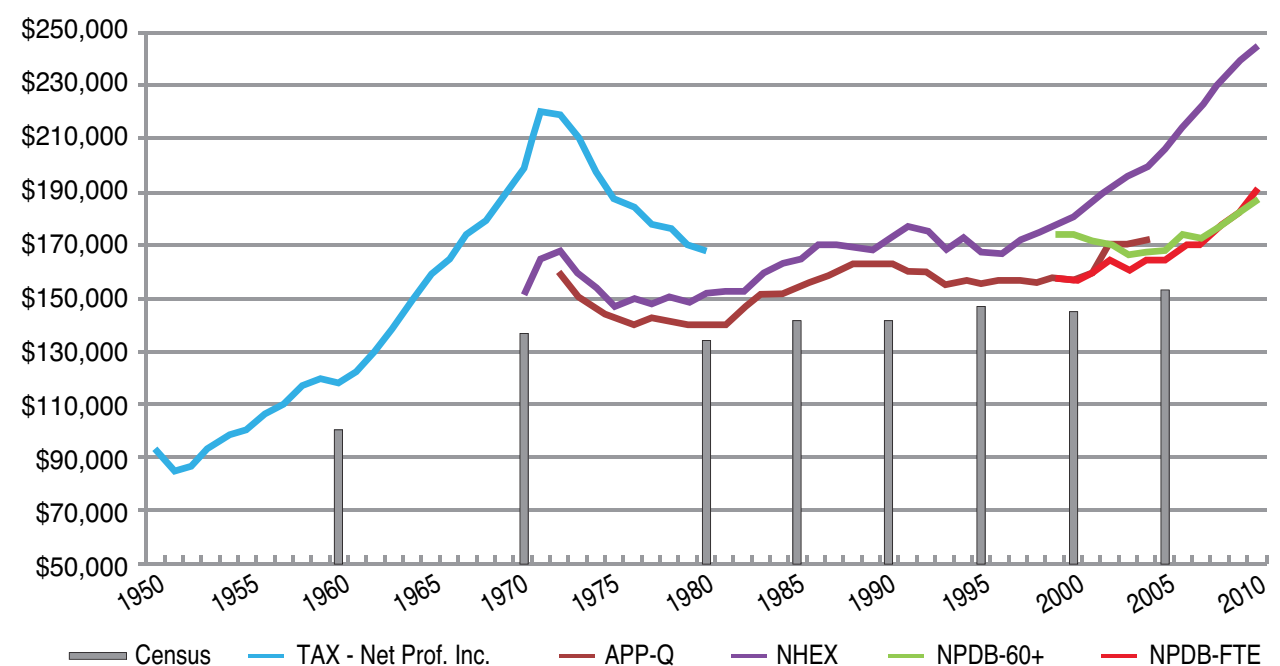





\section{ABOUT THIS PUBLICATION}

The School of Public Policy Research Papers provide in-depth, evidence-based assessments and recommendations on a range of public policy issues. Research Papers are put through a stringent peer review process prior to being made available to academics, policy makers, the media and the public at large. Views expressed in The School of Public Policy Research Papers are the opinions of the author(s) and do not necessarily represent the view of The School of Public Policy.

\section{OUR MANDATE}

The University of Calgary is home to scholars in 16 faculties (offering more than 80 academic programs) and 36 Research Institutes and Centres including The School of Public Policy. Under the direction of Jack Mintz, Palmer Chair in Public Policy, and supported by more than 100 academics and researchers, the work of The School of Public Policy and its students contributes to a more meaningful and informed public debate on fiscal, social, energy, environmental and international issues to improve Canada's and Alberta's economic and social performance.

The School of Public Policy achieves its objectives through fostering ongoing partnerships with federal, provincial, state and municipal governments, industry associations, NGOs, and leading academic institutions internationally. Foreign Investment Advisory Committee of the World Bank, International Monetary Fund, Finance Canada, Department of Foreign Affairs and International Trade Canada, and Government of Alberta, are just some of the partners already engaged with the School's activities.

For those in government, The School of Public Policy helps to build capacity and assists in the training of public servants through degree and non-degree programs that are critical for an effective public service in Canada. For those outside of the public sector, its programs enhance the effectiveness of public policy, providing a better understanding of the objectives and limitations faced by governments in the application of legislation.

\section{DISTRIBUTION}

Our publications are available online at www.policyschool.ca.

\section{DISCLAIMER}

The opinions expressed in these publications are the authors' alone and therefore do not necessarily reflect the opinions of the supporters, staff, or boards of The School of Public Policy.

\section{COPYRIGHT}

Copyright (C) 2013 by The School of Public Policy.

All rights reserved. No part of this publication may be reproduced in any manner whatsoever without written permission except in the case of brief passages quoted in critical articles and reviews.

\section{ISSN}

1919-112x SPP Research Papers (Print)

1919-1138 SPP Research Papers (Online)

\section{DATE OF ISSUE}

July 2013

\section{MEDIA INQUIRIES AND INFORMATION}

For media inquiries, please contact Morten Paulsen at 403-453-0062.

Our web site, www.policyschool.ca, contains more information about The School's events, publications, and staff.

\section{DEVELOPMENT}

For information about contributing to The School of Public Policy, please contact Courtney Murphy by telephone at 403-210-7201 or by e-mail at cdmurphy@ucalgary.ca. 


\section{RECENT PUBLICATIONS BY THE SCHOOL OF PUBLIC POLICY}

CHINA'S STATE-OWNED ENTERPRISES: HOW MUCH DO WE KNOW? FROM CNOOC TO ITS SIBLINGS

http:/ / policyschool.ucalgary.ca/?q=content/ chinas-state-owned-enterprises-how-much-do-we-know-cnooc-itssiblings

Duanjie Chen | June 2013

REPAIRING CANADA'S MINING-TAX SYSTEM TO BE LESS DISTORTING AND COMPLEX

http:/ / policyschool.ucalgary.ca/ ?q=content/ repairing-canadas-mining-tax-system-be-less-distorting-and-

complex

Duanjie Chen and Jack Mintz | May 2013

NOT SO FAST: HOW SLOWER UTILITIES REGULATION CAN REDUCE PRICES AND INCREASE PROFITS http:/ / policyschool.ucalgary.ca/?q=content/ not-so-fast-how-slower-utilities-regulation-can-reduce-prices-andincrease-profits

G. Kent Fellows | May 2013

ALL THE WORKERS WE NEED: DEBUNKING CANADA'S LABOUR-SHORTAGE FALLACY

http:/ / policyschool.ucalgary.ca/ ?q=content/ all-workers-we-need-debunking-canadas-labour-shortage-fallacy Kevin McQuillan | May 2013

NO MORE SECOND-CLASS TAXPAYERS: HOW INCOME SPLITTING CAN BRING FAIRNESS TO CANADA'S SINGLE INCOME FAMILIES

http:/ / policyschool.ucalgary.ca/?q=content/ no-more-second-class-taxpayers-how-income-splitting-can-bringfairness-canadas-single-income

Matt Krzepkowski and Jack Mintz | April 2013

THE IMPORTANCE OF POLICY NEUTRALITY FOR LOWERING GREENHOUSE GAS EMISSIONS

http:// policyschool.ucalgary.ca/sites/default/files/research/greehouse-gas-emissions-final.pdf Trevor Tombe and Jennifer Winter | March 2013

\section{CANADA AND THE CHALLENGES OF CYBERSPACE GOVERNANCE AND SECURITY}

http:/ / policyschool.ucalgary.ca/sites/default/files/research/deibert-cyberspace-final.pdf Ron Deibert | March 2013

\section{CANADIAN MANUFACTURING MALAISE: THREE HYPOTHESES}

http:/ / policyschool.ucalgary.ca/ sites/default/files/research/ canadian-manufacturing-final.pdf Matt Krzepkowski and Jack Mintz | March 2013

APPRECIATE THE APPRECIATION: IMPORTED INPUTS AND CONCERN OVER DUTCH DISEASE

http:/ / policyschool.ucalgary.ca/?q=content/appreciate-appreciation-imported-inputs-and-concern-over-dutchdisease.pdf

Wardah Naim and Trevor Tombe | March 2013

A RECOVERY PROGRAM FOR ALBERTA: A 10-YEAR PLAN TO END THE ADDICTION TO RESOURCE REVENUES http:// policyschool.ucalgary.ca/?q=content/recovery-program-alberta-10-year-plan-end-addiction-resourcerevenues.pdf

Ronald Kneebone and Margarita Gres | March 2013 